\title{
Modeling dust emission response to North Atlantic millennial-scale climate variations from the perspective of East European MIS 3 loess deposits
}

\author{
A. Sima ${ }^{1}$, M. Kageyama ${ }^{2}$, D.-D. Rousseau ${ }^{1,3}$, G. Ramstein ${ }^{2}$, Y. Balkanski ${ }^{2}$, P. Antoine ${ }^{4}$, and C. Hatté ${ }^{2}$ \\ ${ }^{1}$ Laboratoire de Météorologie Dynamique, INSU-CNRS \& CERES-ERTI - UMR8539, Ecole Normale Supérieure, \\ 24 rue Lhomond, 75231 Paris cedex 5, France \\ ${ }^{2}$ Laboratoire des Sciences du Climat et de l'Environnement, CNRS-CEA-UVSQ - UMR8212, CE Saclay, \\ l'Orme des Merisiers, Bât. 701, 91191 Gif-sur-Yvette cedex, France \\ ${ }^{3}$ Lamont-Doherty Earth Observatory of Columbia University, Palisades, NY 10964, USA \\ ${ }^{4}$ Laboratoire de Géographie Physique, CNRS - UMR8591, Université Paris I, place A. Briand, 92158 Meudon cedex, France \\ Correspondence to: A. Sima (adriana.sima@1md.ens.fr)
}

Received: 7 December 2012 - Published in Clim. Past Discuss.: 10 January 2013

Revised: 16 April 2013 - Accepted: 22 May 2013 - Published: 3 July 2013

\begin{abstract}
European loess sequences of the Marine Isotope Stage $3(\sim 60-25 \mathrm{kyr}$ BP) show periods of strong dust accumulation alternating with episodes of reduced sedimentation, favoring soil development. In the western part of the loess belt centered around $50^{\circ} \mathrm{N}$, these variations appear to have been related to the North Atlantic rapid climate changes: the Dansgaard-Oeschger (DO) and Heinrich (H) events. It has been recently suggested that the North Atlantic climate signal can be detected further east, in loess deposits from Stayky $\left(50^{\circ} 05.65^{\prime} \mathrm{N}, 30^{\circ} 53.92^{\prime} \mathrm{E}\right)$, Ukraine. Here we use climate and dust emission modeling to investigate this data interpretation. We focus on the areas north and northeast of the Carpathians, where loess deposits can be found, and the corresponding main dust sources must have been located as well. The simulations were performed with the LMDZ atmospheric general circulation model and the ORCHIDEE land surface model. They represent a reference "Greenland stadial" state and two perturbations, seen as sensitivity tests with respect to changes in the North Atlantic surface conditions between $30^{\circ}$ and $63^{\circ} \mathrm{N}$ : a "Greenland interstadial" and an "H event". The main source for the loess deposits in the studied area is identified as a dust deflation band, with two very active spots located west-northwest from our reference site. Emissions only occur between February and June. Differences from one deflation spot to another, and from one climate state to another, are explained by analyzing the
\end{abstract}

relevant meteorological and surface variables. Over most of the source region, the annual emission fluxes in the "interstadial" experiment are 30 to $50 \%$ lower than the "stadial" values; they would only be about $20 \%$ lower if the inhibition of dust uplift by the vegetation were not taken into account. Assuming that lower emissions result in reduced dust deposition leads us to the conclusion that the loess-paleosol stratigraphic succession in the Stayky area reflects indeed North Atlantic millennial variations. In the main deflation areas of Western Europe, the vegetation effect alone determined most of the ( $\sim 50 \%$ on average) stadial-interstadial flux differences. Even if its impact in Eastern Europe is less pronounced, this effect remains a key factor in modulating aeolian emissions at the millennial timescale. Conditions favorable to initiating particularly strong dust storms within a few hundred kilometers upwind from our reference site, simulated in the month of April of the $\mathrm{H}$ event experiment, support the correlation of $\mathrm{H}$ events with peaks in grain size index in some very detailed loess profiles, indicating increased coarse sedimentation.

\section{Introduction}

In Europe, a west-east eolian corridor was formed in glacial times between the British and Fennoscandian ice sheet to the 


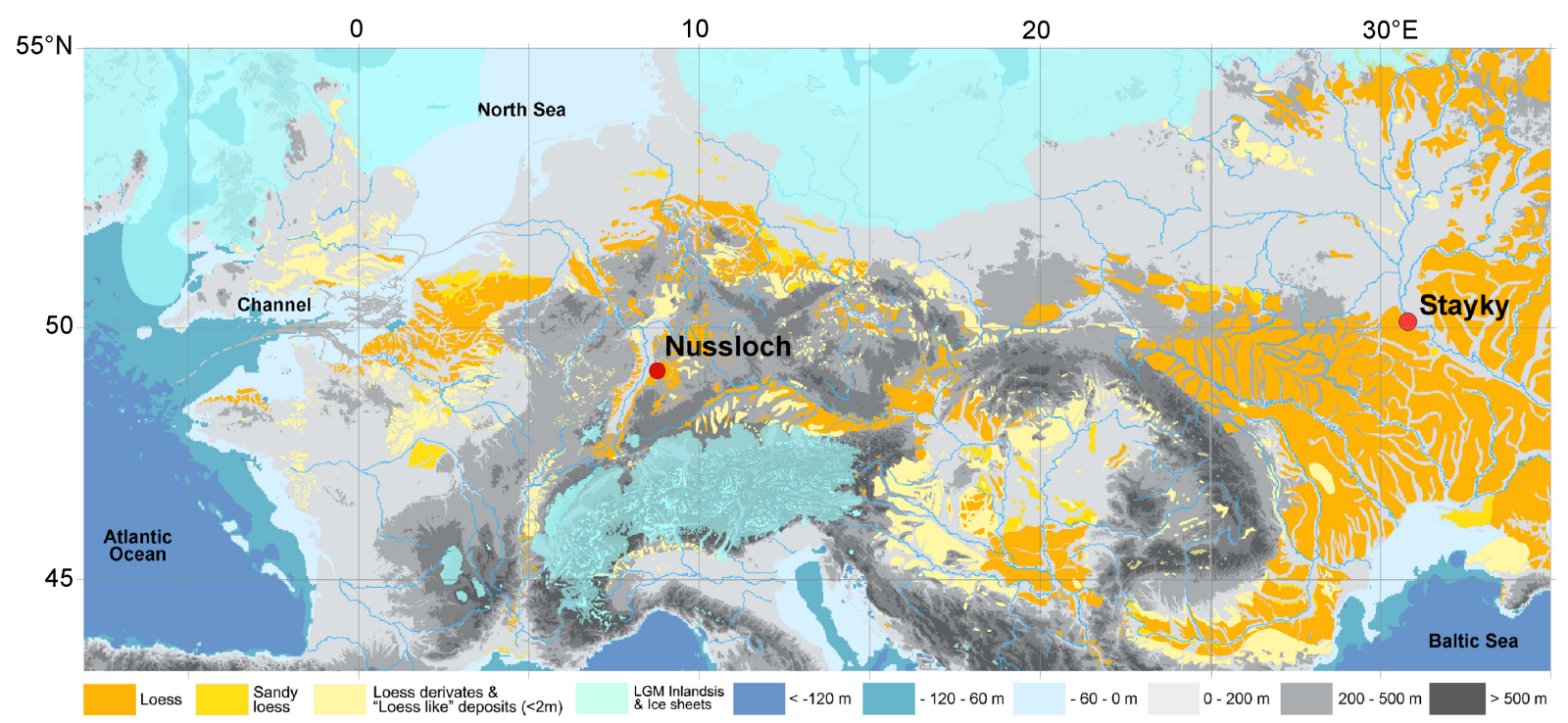

Fig. 1. Map of the thickest European loess deposits (in yellow), in the context of the Last Glacial Maximum (21 kyr BP) ice sheets (light blue) and sea level (modified from Antoine et al., 2013, based on data from compilations kindly provided by D. Haase from Haase et al., 2007, and J. Ehlers from Ehlers et al., 2011). Blue/gray colors indicate depth/elevation with respect to the actual sea level.

north and the relatively high midlatitude European relief (including the Alpine glacier) to the south (Fig. 1). Vast areas along this corridor are generally flat (below $200 \mathrm{~m}$ altitude), with the geological substratum mostly represented by relatively easily erodible Tertiary or Cretaceous rocks (Asch, 2005), and have periodically been subject to strong dust deflation under glacial climate conditions. Deflatable material with a large range of grain sizes was made available by a variety of mechanisms acting at local or regional scales, at timescales from seasonal to millennial and orbital: the exposure of the continental shelf due to sea level lowering, grinding of rocks by ice sheets and glaciers, frost weathering, fluvial erosion by periglacial rivers, eolian erosion by strong glacial winds, accentuated by a reduced vegetation cover in a much colder and dryer climate than today. Particularly rich in easily deflatable sand and silts were the exposed continental shelves and the periglacial outwash plains, as well as the periglacial river valleys, mostly dried-out outside of the snowmelt period. Part of the material deflated in these source areas has accumulated in the south of the eolian corridor, forming a loess belt at about $50^{\circ} \mathrm{N}$ latitude. Some of the deposition areas, located in a relief context allowing dust remobilization, could have been "secondary dust sources".

Loess sedimentation rates have strongly varied at millennial timescales, especially during Marine Isotope Stage 3 (MIS 3, 58 900-24 $100 \mathrm{yr} \mathrm{BP;} \mathrm{Martinson} \mathrm{et} \mathrm{al.,} \mathrm{1987).}$ High-resolution studies on sequences from Nussloch, Germany (Rousseau et al., 2007; Antoine et al., 2009), have suggested that the sedimentation variations in Western Europe were correlated with the abrupt climate changes known as Dansgaard-Oeschger (DO) events (Dansgaard et al., 1993) and Heinrich (H) events (Heinrich, 1988; Broecker et al.,
1992). The North Atlantic cold episodes identified in ice or marine cores, i.e., Greenland stadials (North Greenland Ice Core Project, 2004; Rousseau et al., 2006) and H events, appear to correspond to periods of loess accumulation, indicating a very active dust cycle caused by dry and windy conditions. The warmer "Greenland interstadials" were associated with moister and less windy conditions on the continent, with a less active dust cycle, favoring soil formation. Alternating loess-paleosol units are recognizable especially after $40 \mathrm{kyr}$ BP, when the main loess sedimentation interval in Europe begins.

Rapid environmental changes have also been identified in loess sequences further east (Haesaerts et al., 2003; Rousseau et al., 2001, 2007, 2011; Gerasimenko and Rousseau, 2008; Antoine et al., 2009). They are expressed in the loesspaleosol stratigraphic succession, and in the variations of different indices: grain size index, magnetic properties, carbon isotope ratios, and, where available, in the pollen records. Following investigations by Kukla (1977), a link between Central and Eastern Europe was established on the basis of sequences from Dolní Věstonice, in the Czech Republic (e.g., Fuchs et al., 2012; Antoine et al., 2013), and Vyazivok, in the Ukraine (e.g., Rousseau et al., 2001). Recently, using high-resolution data from Nussloch, Germany, and another Ukrainian site, Stayky, Rousseau et al. (2011) suggested that the North Atlantic climate signal has been recorded throughout the European loess band, at least as far as $30^{\circ} \mathrm{E}$.

In a previous study, we have used an atmospheric general circulation model (AGCM) and offline dust emission calculations to investigate the impact of North Atlantic millennial climate changes on dust emission variations in Western Europe (Sima et al., 2009). Three numerical simulations were 
run, designed as sensitivity experiments with respect to SST variations in the North Atlantic as those associated with DO and $\mathrm{H}$ events. We have analyzed the main Western European deflation areas, with focus on the exposed continental shelf in the English Channel and the North Sea (Juvigné, 1976; Auffret, 1980; Auffret et al., 1982; Lautridou et al., 1985; Antoine et al., 2003a,b). The main results consisted of (a) a strong seasonality of emissions, which occurred overall between February and June (with differences from one climate state to another), when the snow was melting, the soil was drying, and the vegetation was still sparse enough to allow for dust deflation; and (b) considerably lower emission fluxes in the Greenland interstadial experiment than in the Greenland stadial and $\mathrm{H}$ event simulations, supporting the interpretation of loess sedimentation variations as being produced by the North Atlantic millennial variability. It was also shown that the vegetation, which inhibits eolian erosion, has played a key role in determining the seasonal cycle of emissions and the differences of dustiness between the relatively warm versus cold North Atlantic phases.

Following the data study by Rousseau et al. (2011), which proposed a correlation between Greenland, West and East European dust records, here we focus on Eastern Europe. We use the same AGCM simulations and dust emission calculations as in Sima et al. (2009), combined with information from the loess site of Stayky, in Ukraine (briefly described in Sect. 2).

After identifying the potential sources for the dust deposited around this site (Sect. 3.1), we investigate the impact of North Atlantic SST changes on dust emission in these areas. The "dusty season" is determined (Sect. 3.2), and the relevant climate variables and surface conditions are analyzed on average over this period of the year (Sect. 3.3), with special attention to the role of vegetation. Furthermore, we examine in detail the hypothesis that $\mathrm{H}$ events could correspond in European loess sequences to intervals of particularly coarse sedimentation (Rousseau et al., 2007, 2011). Finally, we discuss the results (Sect. 4), draw conclusions and give some perspectives (Sect. 5).

\section{Reference loess site, numerical simulations, and dust emission calculations}

The reference loess site for this study is Stayky $\left(50^{\circ} 05.65^{\prime} \mathrm{N}\right.$, $30^{\circ} 53.92^{\prime} \mathrm{E}, 194 \mathrm{~m}$ a.s.l.), in Ukraine, located by the Dnieper River, about $50 \mathrm{~km}$ south of Kiev. This outcrop was chosen for its detailed record of the last climate cycle, during a preliminary investigation of the numerous outcrops of the loess series studied in the area (Gerasimenko and Rousseau, 2008). It is situated on a cliff ending the plateau on the right bank of the river; the Dnieper River floodplain lies on the left bank. The sequence corresponding to the last climatic cycle has been studied at high resolution by defining a precise stratigraphy, sampling continuously for grain size analysis, and taking sediment for optically stimulated luminescence dating (Rousseau et al., 2011). For the interval 38 to $18 \mathrm{kyr} \mathrm{BP}$, alternating loess and embryonic soils similar to the loess-paleosol doublets observed at Nussloch (Germany) have been identified, as well as a similar pattern of the grain size index variations. A correlation was proposed between the loess-embryonic soil doublets and the Greenland stadialinterstadial climate cycles. Also, it was suggested that two particular peaks of the grain size index might correspond to $\mathrm{H}$ events 3 and 2.

The simulations have been carried out with the LMDZ.3.3 atmospheric general circulation model (Jost et al., 2005) including the ORCHIDEE land surface model (Ducoudre et al., 1993; Krinner et al., 2005). Inspired by the GS9-H4GIS8 sequence around the H4 event $(\sim 39 \mathrm{kyr}$ BP; Bard et al., 2004), they represent a reference glacial state (Greenland stadial, GS), a cold (H event, HE) and a warm (DansgaardOeschger, or Greenland interstadial, GIS) perturbation. Thus, the orbital parameters (Berger, 1978; Berger and Loutre, 1991 ) were set to $39 \mathrm{kyr} \mathrm{BP}$ values, and the $\mathrm{CO}_{2}$ concentration to 209 ppmv (Petit et al., 1999). The ice sheet configuration at $14 \mathrm{kyr}$ BP was selected from the ICE-4G reconstruction (Peltier, 1994) as corresponding to a sea level similar to that at $39 \mathrm{kyr} \mathrm{BP}$, approximately $60 \mathrm{~m}$ lower than today (Siddall et al., 2008). The land-sea mask of the LMDZ and SECHIBA models was adapted to this sea level. In the absence of reconstructions or climate model results for the MIS 3 sea surface temperatures (SSTs) and sea ice at the time when we ran the simulations, the GLAMAP2000 reconstruction (Sarnthein et al., 2003) for the Last Glacial Maximum (LGM, approximately between 23 and $18 \mathrm{kyr}$ BP) was used in the reference glacial climate simulation GS. The cold and warm perturbations were obtained by only altering the North Atlantic surface conditions in the latitudinal band between $30^{\circ} \mathrm{N}$ and $63^{\circ} \mathrm{N}$. All-year-long zonal SST anomalies of up to $\pm 2{ }^{\circ} \mathrm{C}$ (Cortijo et al., 1997) were applied in this band, and sea ice was imposed where the SST was lower than $-1.8^{\circ} \mathrm{C}$. The simulations are thus sensitivity experiments with respect to variations in the North Atlantic surface conditions as those associated with $\mathrm{DO}$ and $\mathrm{H}$ events. In the following, we will use "H-stadial" when specifically referring to the cold climate interval associated with an $\mathrm{H}$ event (defined as an episode of massive iceberg release recorded in marine sediments by layers rich in ice-rafted debris).

In the ORCHIDEE model version we have used here (Krinner et al., 2005), the computed leaf area index (LAI) varies between minimum and maximum values fixed for each plant functional type (PFT) to standard values based on averaged observations, and is only modulated by the AGCM-derived temperature. The maximum grid-cell fraction that can be occupied by each PFT is also prescribed. In our paleoclimate experiments we kept the present-day values, as recommended by the Paleoclimate Modelling Intercomparison Project (PMIP; e.g., Braconnot, 2004) for the LGM simulations. The actual grid-cell fraction covered by 


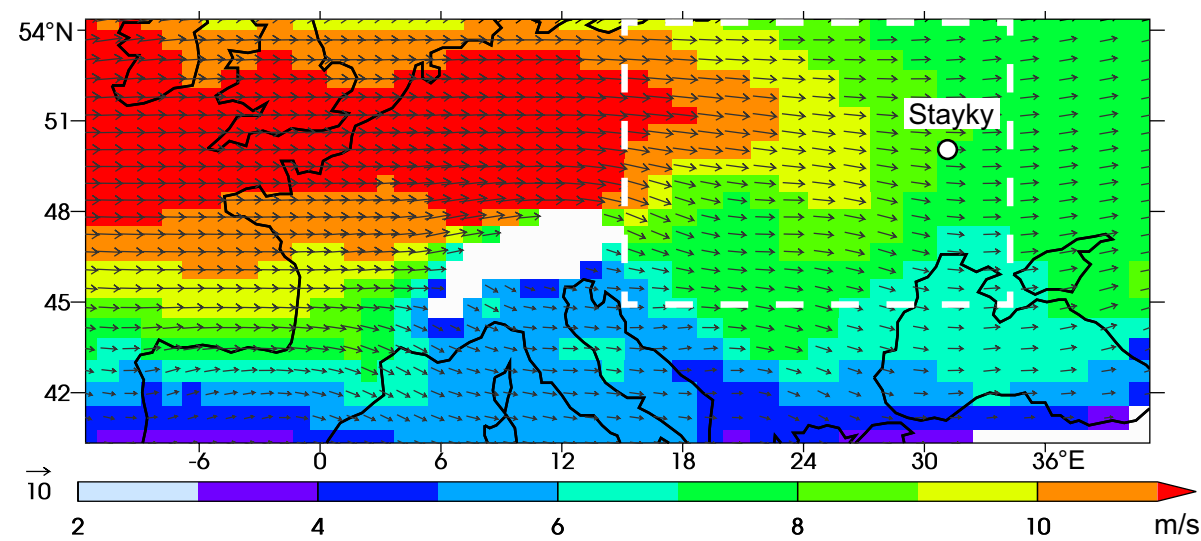

Fig. 2. Mean annual $850 \mathrm{hPa}$ wind speed and direction for the reference GS state (modified from Rousseau et al., 2011). The area investigated in this study stretches between $15-35^{\circ} \mathrm{E}$ and $45-55^{\circ} \mathrm{N}$.

a PFT depends on the imposed maximum vegetation fraction and the computed LAI. In each experiment, the LMDZORCHIDEE model was run for a spin-up period of one year, followed by $20 \mathrm{yr}$ that were analyzed.

The Sima et al. (2009) study has shown the importance of vegetation, as an inhibitor of aeolian erosion, in modulating dust emission at millennial timescales in the Western European deflation areas. Therefore, here we calculate again separately the emitted "dry" dust flux $F_{\mathrm{d}}$, taking into account all factors but the vegetation effect, and the $F$ flux including the vegetation effect. These fluxes are given by the following formulas:

$$
\begin{aligned}
F_{\mathrm{d}}= & C^{\prime} \cdot f_{\mathrm{d}} \cdot w_{10 \mathrm{~m}}^{2} \cdot\left(w_{10 \mathrm{~m}}-w_{\mathrm{th}}\right) \\
& \quad \text { for } w_{10 \mathrm{~m}}>w_{\mathrm{th}}\left(F_{\mathrm{d}}=0 \text { otherwise }\right)
\end{aligned}
$$

and

$$
\begin{aligned}
F= & F_{\mathrm{d}} f_{\mathrm{v}}=C^{\prime} \cdot E \cdot w_{10 \mathrm{~m}}^{2} \cdot\left(w_{10 \mathrm{~m}}-w_{\mathrm{th}}\right) \\
& \text { for } w_{10 \mathrm{~m}}>w_{\mathrm{th}}(F=0 \text { otherwise }) .
\end{aligned}
$$

- $C^{\prime}$ is a constant for every grid cell that only depends on intrinsic characteristics such as the surface roughness (vegetation excluded), grain size distribution and texture of the bare soil. Here we take $C^{\prime}=5 \times 10^{-7} \mathrm{~g} \mathrm{~m}^{-5} \mathrm{~s}^{2}$ everywhere in our domain of study, an intermediate value in the range of those determined by Balkanski et al. (2004) for the present-day arid and semi-arid regions.

- $f_{\mathrm{d}}$, which we call "dry soil fraction", quantifies the soil water effect on dust emission. It equals the snow-free fraction of the grid cell if the soil is dry at more than $5 \mathrm{~mm}$ depth, and is 0 otherwise.

- $f_{\mathrm{v}}$, the vegetation factor, quantifies the vegetation effect of inhibiting wind erosion. It is calculated as a function of the vegetated soil fraction $f_{\text {veg }}$, following Eq. (6) of Fryrear (1985), and is corrected at low $(<10 \%)$ and high $(>60 \%)$ vegetation cover:

$$
\begin{aligned}
f_{\mathrm{v}}= & \min \left(1,1.81 \cdot \exp \left(-7.2 \cdot f_{\mathrm{veg}}\right)\right) \\
& \text { if } f_{\mathrm{veg}}<0.6, \text { and } f_{\mathrm{v}}=0 \text { otherwise. }
\end{aligned}
$$

- $E=f_{\mathrm{d}} \cdot f_{\mathrm{v}}$ is the "erodible fraction", and represents the grid-cell fraction where dust emission is allowed at any given moment by both soil humidity and vegetation effects.

- $w_{10 \mathrm{~m}}$ is the 6-hourly averaged $10 \mathrm{~m}$ wind computed by the atmospheric model.

- $w_{\text {th }}$ is the threshold wind speed for erosion, determined for each grid cell, same as $C^{\prime}$, by the intrinsic (bare) soil characteristics. As in Sima et al. (2009), a constant value is used everywhere: $7 \mathrm{~m} \mathrm{~s}^{-1}$, close to the lowest values for the present-day deserts, either measured (Wang et al., 2003) or derived as a function of soil characteristics (Marticorena and Bergametti, 1996; Laurent et al., 2005).

\section{Results}

\subsection{Potential dust sources}

In order to determine where the main source areas must have been located with respect to the Stayky loess site, we analyze the wind direction at the surface and at altitude. We take the $850 \mathrm{hPa}$ level (corresponding on average to an altitude of about $1500 \mathrm{~m}$ a.s.l.) as relevant for the medium- to longdistance dust transport. The mean annual wind direction at this level has a strong westerly component in the reference state (Fig. 2), as well as in the two perturbations (Rousseau et al., 2011, Fig. 5 therein). More important, considering the strong seasonality of emissions for Western Europe (Sima 

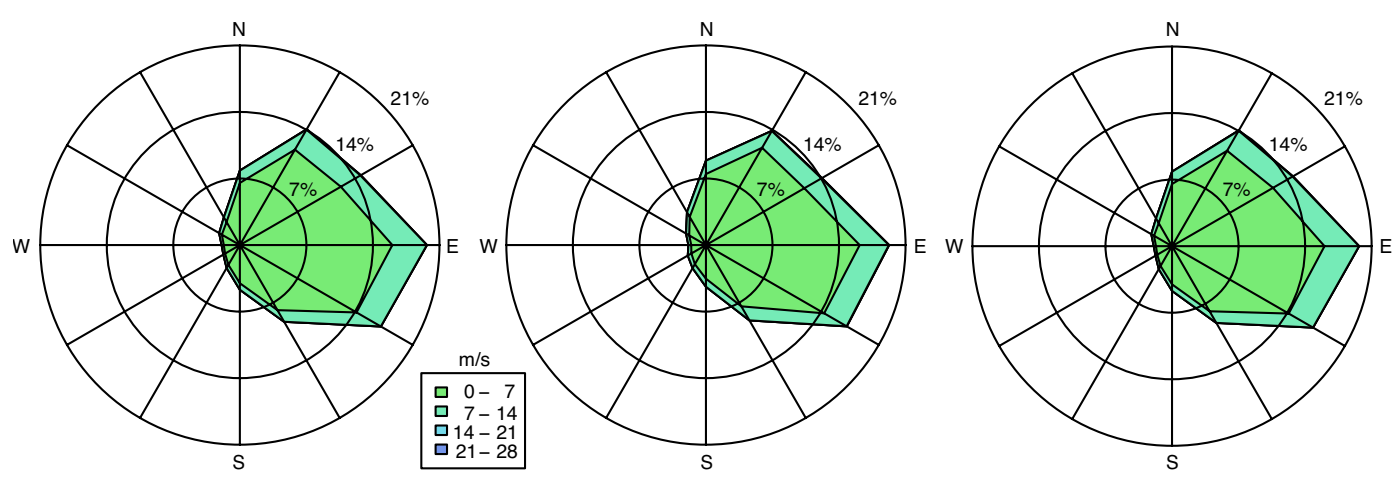

Fig. 3. $10 \mathrm{~m}$ wind roses derived from 6-hourly $10 \mathrm{~m}$ winds at Stayky for $20 \mathrm{yr}$ of simulation for each of the three climate states. Relevant winds for dust emission are those exceeding the threshold erosion wind speed, $7 \mathrm{~m} \mathrm{~s}^{-1}$ in this study. Winds below $14 \mathrm{~m} \mathrm{~s}^{-1}$ are much more frequent than those above $14 \mathrm{~m} \mathrm{~s}^{-1}$ (which cannot even be seen on the plots), and determine most of the emitted amount of dust (cf. Sima et al., 2009).

et al. 2009), the strong westerly component is also found in monthly averages (not shown). To identify the most probable position of the local source areas with respect to the site, we examine the wind roses derived from 6-hourly $10 \mathrm{~m}$ winds for the $20 \mathrm{yr}$ analyzed for each simulation (Fig. 3). Again, in all three states, westerly wind occurrences greatly exceed the easterly ones. This explains why, despite the large amount of sand available in the Dnieper River floodplain, east of Stayky, very little sand is found in the loess deposit (Rousseau et al., 2011). Also, the loess site is located approximately $150 \mathrm{~m}$ higher than the valley, so the sand in the loess profile must have been transported during rare strong easterly wind events.

The $10 \mathrm{~m}$ wind-speed values are up to $20 \mathrm{~m} \mathrm{~s}^{-1}$ for the GS state, up to $21 \mathrm{~m} \mathrm{~s}^{-1}$ for GIS, and about $22 \mathrm{~m} \mathrm{~s}^{-1}$ for $\mathrm{HE}$, but the frequency of strong winds, exceeding $14 \mathrm{~m} \mathrm{~s}^{-1}$, is not high enough to see in the plots. According to Sima et al. (2009), the yearly averaged dust fluxes are not controlled by the strongest winds, but rather by the much more frequent medium wind-speed category (from 9 to $14 \mathrm{~m} \mathrm{~s}^{-1}$ in the case of the Western European main sources). For HE, the strongest $10 \mathrm{~m}$ wind events, exceeding $20 \mathrm{~m} \mathrm{~s}^{-1}$, occur in April and December (not shown). We will discuss this result in Sect. 3.2, where we look at dust emission seasonality and the relationship with the identification of $\mathrm{H}$ events in loess sediments as peaks in the grain size index.

Finally, considering the low end of the grain size range in the Stayky profile (the clay fraction, with diameters up to a few microns), most of the constituting material has probably originated from sources not more than a thousand kilometers away from the site (Rousseau et al., 2011). All these taken into account, we consider that the main potential dust sources for Stayky must have been located between $15^{\circ}$ and $35^{\circ} \mathrm{E}$. This is the longitudinal range for which we will perform the dust emission calculations. The latitudinal range of interest spans over a $10^{\circ}$-wide band centered on Stayky: from $45^{\circ} \mathrm{N}$, the latitude of the southern Carpathians, to $55^{\circ} \mathrm{N}$, in the Baltic Sea, and close to the Fennoscandian ice sheet southern limit on the continent around $40 \mathrm{kyr} \mathrm{BP}\left(\sim 57^{\circ} \mathrm{N}\right.$ in our experimental setup; cf. the ICE-4G reconstruction). The resulting domain is shown in Fig. 2. When representing dust fluxes or surface conditions, we exclude the Carpathians (by masking the areas with altitudes exceeding $500 \mathrm{~m}$ ), where no relevant emission may occur. We also exclude the lowlands inside the mountain arch, as they are unlikely to have contributed to dust deposition in the $\sim 50^{\circ} \mathrm{N}$ band examined in this study.

For each simulated climate state, we compute yearly averaged dust emission fluxes over the domain of interest (Fig. 4). In all climate states, emission mainly occurs in a NW-SE band, located north and northeast of the Carpathians (Fig. 5). Two spots appear as most active with respect to climaterelated conditions and are placed west-northwest of Stayky, constituting potential source areas for this reference site. The one closest to Stayky, hereafter referred to as "Spot 1", is in Ukraine, centered at about $51^{\circ} \mathrm{N}, 26^{\circ} \mathrm{E}$ (S1 in Fig. 4a). It partly covers areas where loess deposits are located (Fig. 5), which means that here dust remobilization might have been important. The second most active region, "Spot 2", is in Poland, centered at about $53^{\circ} \mathrm{N}, 19^{\circ} \mathrm{E}$ (S2 in Fig. 4a).

The extent of the potentially most active sources does not change significantly from the GS to the HE climate state (Fig. 4a and b), but annual mean dust fluxes are smaller for HE than for GS, especially over Spot 2. A shrinking of the potential emission area can be seen for the GIS compared to GS, as well as a decrease, stronger than in the HE case, of the annual mean dust emission fluxes (Fig. 4c).

To explain the spatial distribution of the potential deflation areas and the differences of dustiness between the simulated climate states (Fig. 4), we need to examine the variations of the relevant climate variables - wind, precipitation, and temperature - as well as the surface conditions determined by these variables - soil humidity, snow and vegetation covers. The annual or seasonal means of these quantities are not 
(a) $\mathrm{F}(\mathrm{g} \mathrm{m}-2 \mathrm{yr}-1)$ GS

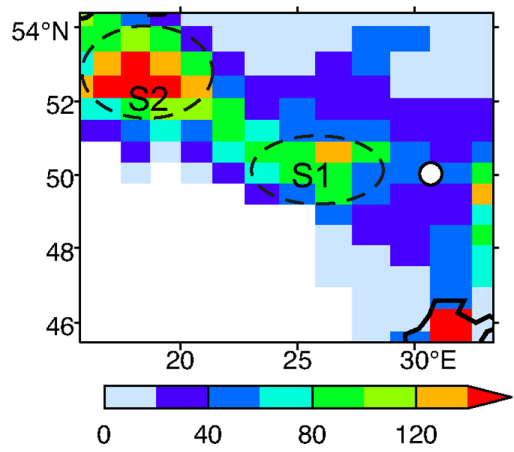

(b) $F($ g m-2 yr-1) HE

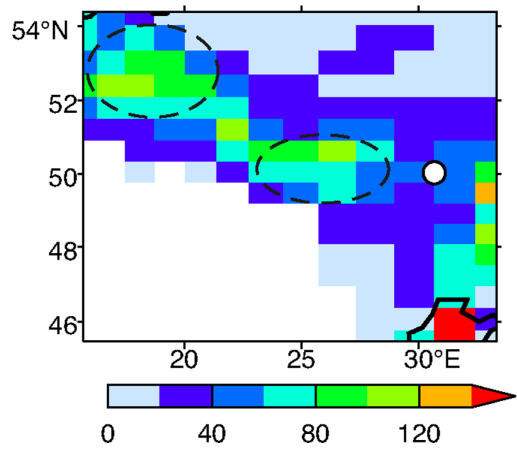

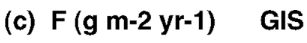

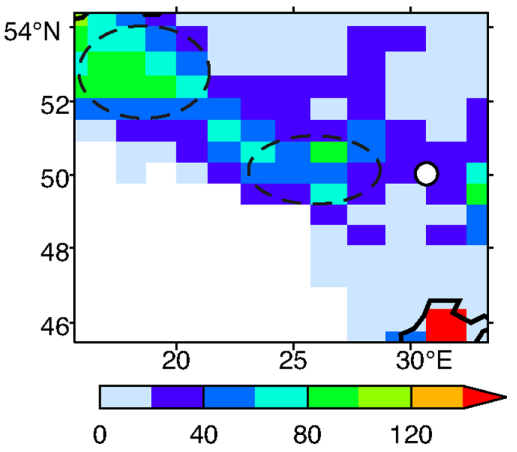

Fig. 4. Annual means of dust emission fluxes $F\left(\mathrm{~g} \mathrm{~m}^{-2} \mathrm{yr}^{-1}\right)$, calculated including the vegetation effect, for the three simulated climate states: GS (left panel), HE (middle panel), and GIS (right panel). Emission mainly occurs in a NW-SE band, with S1 and S2 being the most active spots.

quite relevant for this matter (see Sima et al., 2009), so we first determine the period of the year when dust emission occurs over our area of study, and then analyze the variables of interest as averages of this period.

\subsection{Seasonality of emissions}

Sima et al. (2009) have shown the strongly seasonal nature of dust emission occurrence over the large deflation areas formed by sea level lowering in the English Channel and the south of the North Sea. Here, we study the same latitude range, and the annual cycle of the main variables impacting dust emission resembles that for the west of Europe (Fig. 5a and $b$ in Sima et al., 2009). Winter is characterized by strong winds and scarce vegetation, but snow cover and the high soil humidity prevent dust from being uplifted. Conversely, in summer the wind weakens and, as the soil dries up, the development of vegetation becomes the main surface process blocking dust mobilization. These different conditions constraining dust emission determine the potential deflation areas, and their seasonality. Thus, in our domain of interest, the main emission band located north and northeast of the Carpathian Mountains is most active in springtime, when the wind, soil humidity and vegetation conditions are simultaneously favorable (Fig. 6). As in the Western European source areas, the seasonal evolution of dust emission intensity differs from one climate state to another. Furthermore, for each climate state, the two most active spots show noticeable differences in their seasonality. Spot 1 is the first to start emitting dust: in February for GS and GIS, and in March for HE. In all three states, the most active period is April. The conditions become unfavorable to dust emission in May for GIS, and in June for the other two states.

Spot 2 has the same general evolution, but with one month of delay with respect to Spot 1 . It starts to significantly emit in March for GS and GIS, and in April for HE. For GS and $\mathrm{HE}$ it is most active in May, and stops emitting in June, whereas for GIS the emissions cease one month earlier.

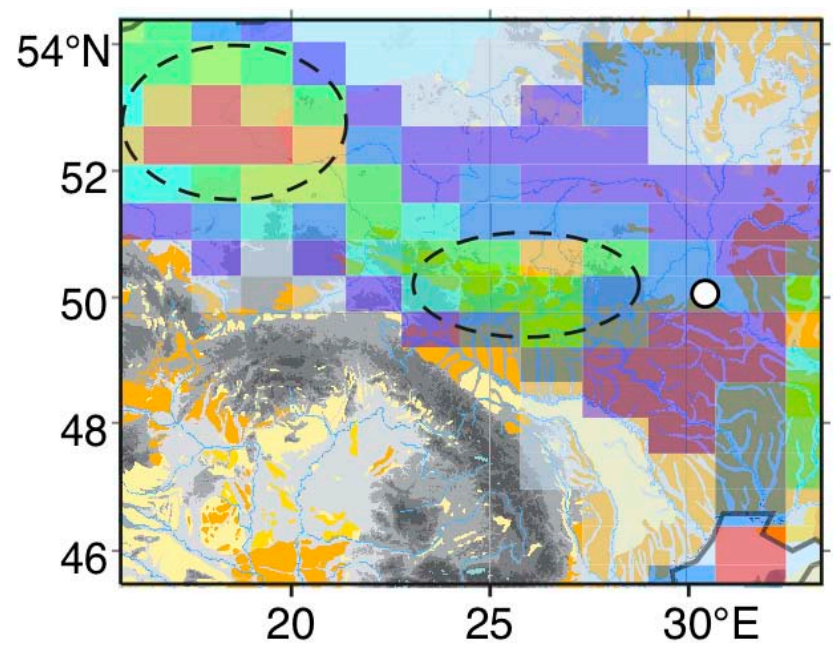

Fig. 5. Annual mean of dust emission fluxes for GS (Fig. 4a) superimposed on the topographic map.

If we consider the two most active areas together, the dusty season in our region of interest lasts from February to June in the stadial state, from March to June in the HE state, and from February to May in the interstadial state. For all months and climate states, the average $850 \mathrm{hPa}$ winds are from west or west-northwest (Fig. 6), so that the deflation band we have identified may feed the European aeolian deposits located farther eastward (Fig. 1). Considering the distance to our reference site ( $\sim 300 \mathrm{~km}$ for Spot 1, $800 \mathrm{~km}$ for Spot 2$)$, and the monthly means of $850 \mathrm{hPa}$ wind direction over the emission season, Spot 1 is the best candidate as a dust source for the loess deposits in the Stayky area. Spot 2 certainly contributes as well, even though (again, considering the monthly means of $850 \mathrm{hPa}$ wind direction in Fig. 6) much of the dust emitted here is probably transported on a more northern path. 


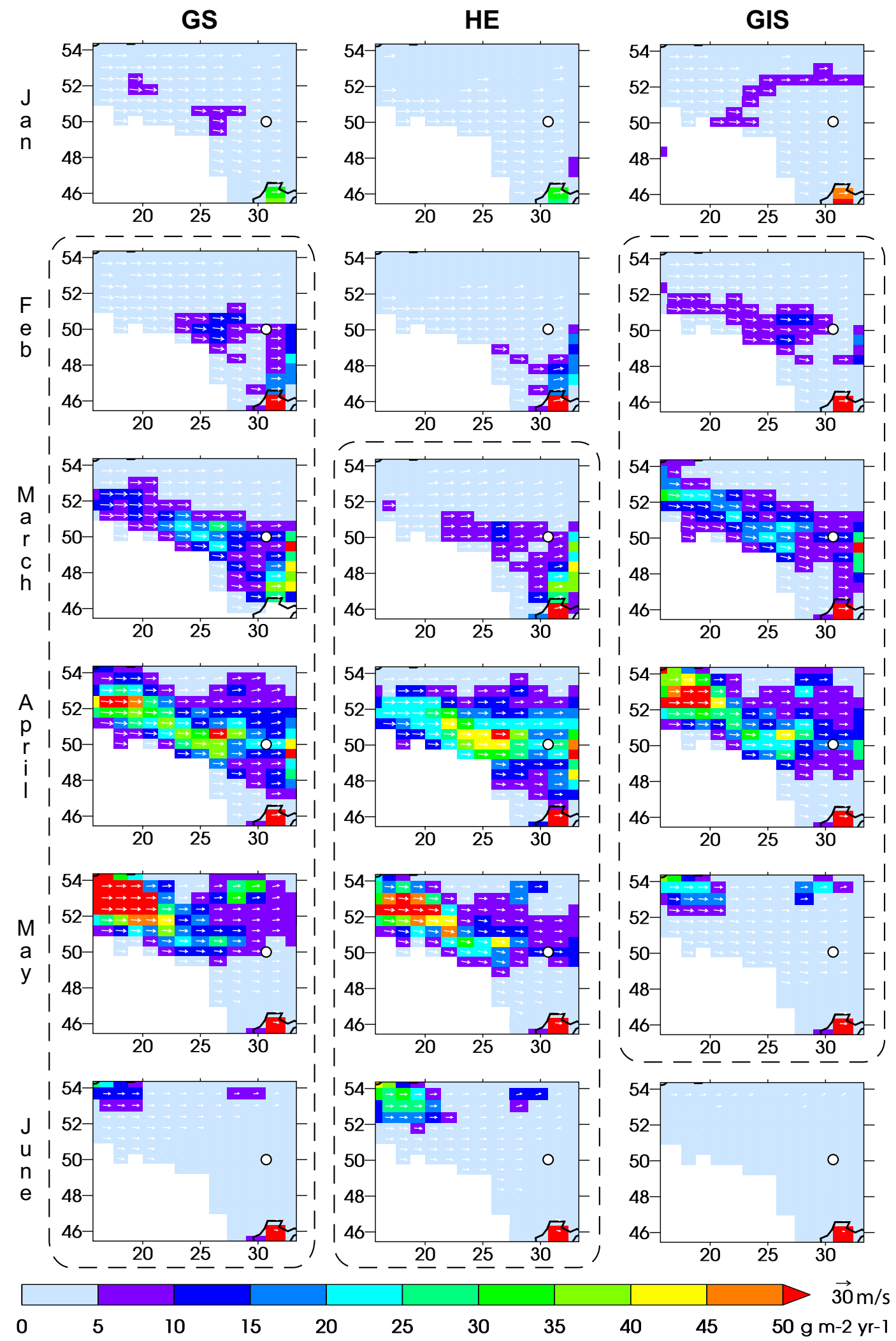

Fig. 6. Monthly means of dust emission fluxes outside the Carpathians in the three simulated climate states for January to June (for each panel, the $\mathrm{x}$-axis represents longitude $\left({ }^{\circ} \mathrm{E}\right)$, and the $\mathrm{y}$-axis latitude $\left.\left({ }^{\circ} \mathrm{N}\right)\right)$. Wherever the slightest emission occurs, the monthly average wind vectors at $850 \mathrm{hPa}$ indicate the direction in which the dust is most likely transported. Little or no dust is emitted in this area during the rest of the year. 


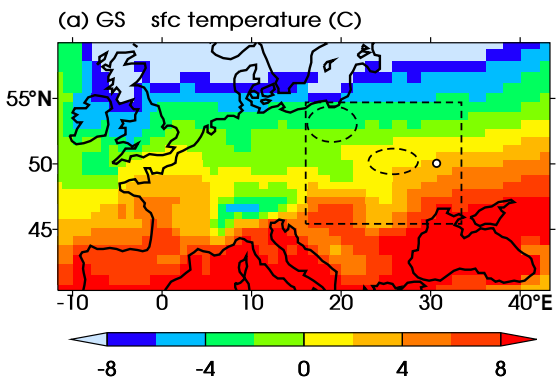

(d) GS precipitation ( $\mathrm{mm} /$ day)

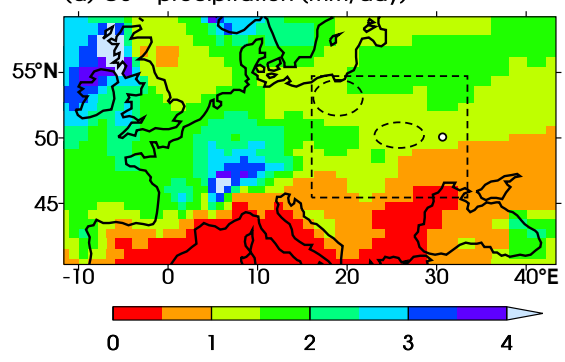

(g) GS $10 \mathrm{~m}$-wind $(\mathrm{m} / \mathrm{s})$

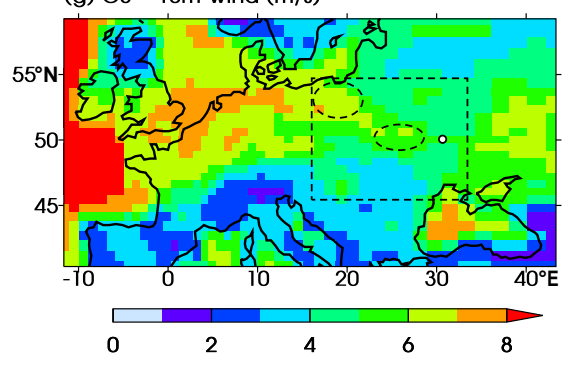

(b) HE-GS sfc temperature (C)

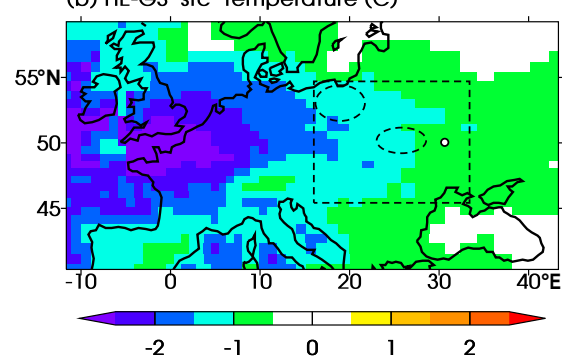

(e) HE-GS precipitation (mm/day)

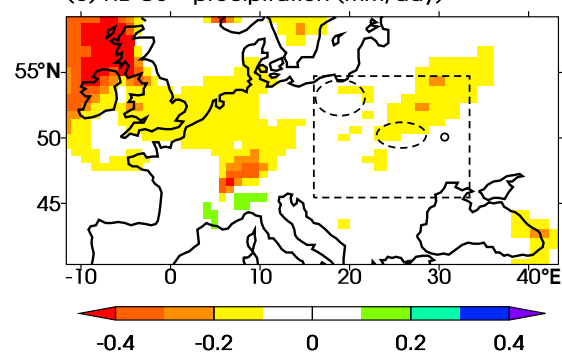

(h) HE-GS $10 \mathrm{~m}$-wind $(\mathrm{m} / \mathrm{s})$

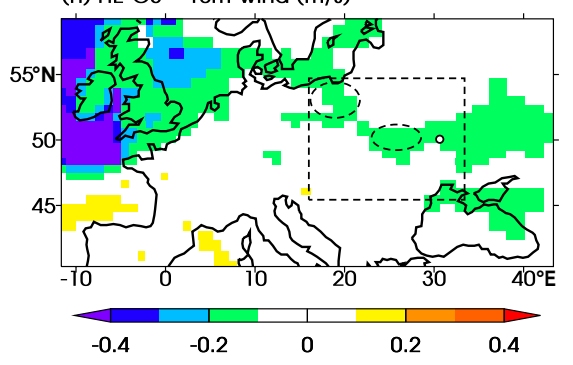

(c) GIS-GS sfc temperature (C)

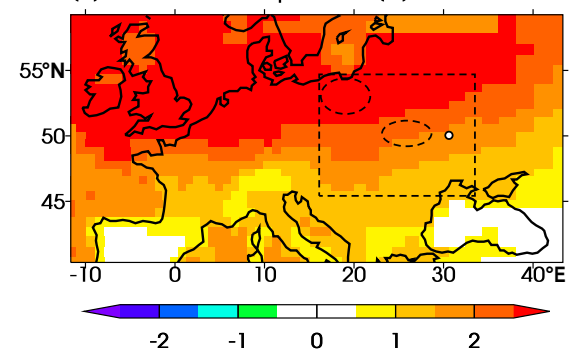

(f) GIS-GS precipitation (mm/day)

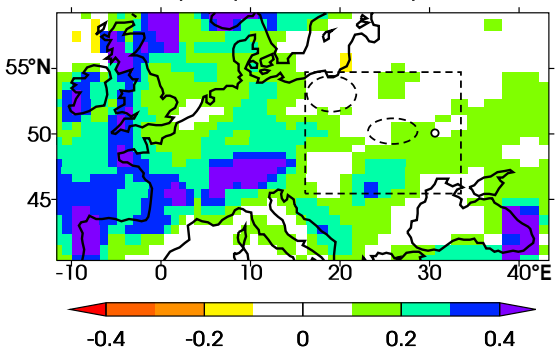

(i) GIS-GS $10 \mathrm{~m}$-wind $(\mathrm{m} / \mathrm{s})$

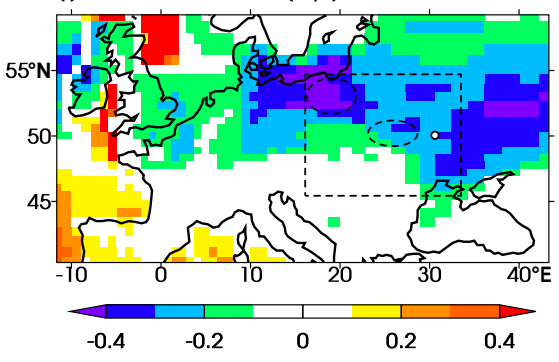

Fig. 7. February to June averages of $2 \mathrm{~m}$ temperature (a-c), precipitation (d-f) and $10 \mathrm{~m}$ wind (g-i) for the GS state (left column), and anomalies HE-GS (center column) and GIS-GS (right column). In white are areas where the differences are not significant at the $95 \%$ confidence level (Student's $t$ test on a series of 20 data points, representing the averages of the February to June interval from the $20 \mathrm{yr}$ of run for each climate state).

\subsection{Climate variables, surface conditions and dust emission}

To explain the spatial distribution of the potential deflation areas, the differences of dustiness and seasonality between the two most active spots, and those differences between the simulated climate states (Figs. 4 and 6), we need to examine the relevant climate variables and surface conditions. As shown in Sect. 3.2, for all simulated climate states, the annual amount of dust is only produced over a period between February and June. Therefore, in the following, we analyze the variables and anomalies of interest as averages over this "dusty season".

The climate variables we address are (Fig. 7) (i) $2 \mathrm{~m}$ temperature, which impacts soil humidity (through evaporation), snow cover extent and duration, and vegetation development; (ii) precipitation, which in our study only impacts soil humidity and snow cover, not vegetation (cf. Sect. 2.1); and (iii) $10 \mathrm{~m}$ wind, on which dust emission fluxes strongly depend (cf. Sect. 2). For the surface conditions, we examine
(Fig. 8) the dry fraction $f_{\mathrm{d}}$, the vegetation factor $f_{\mathrm{v}}$ and the resulting erodible fraction $E=f_{\mathrm{d}} \cdot f_{\mathrm{v}}$.

\subsubsection{The reference GS state}

We focus on the domain for which we performed the dust calculations, $45-55^{\circ} \mathrm{N}, 15-35^{\circ} \mathrm{E}$, and on the resulting dust emission band shown in Fig. 4. In the reference GS state, the average temperature over the investigated domain follows a north-south gradient, with values ranging approximately from $-4^{\circ}$ to $6^{\circ} \mathrm{C}$ (Fig. 7a). This leads to a faster snow melting and an enhanced surface evaporation in the southeast (SE) part compared to the northwestern (NW) part of the emissions band (not shown). Precipitation averages are between 1 and $1.5 \mathrm{~mm} \mathrm{day}^{-1}$, slightly lower in the SE (Fig. 7d). These combined factors give better conditions for emission with respect to soil humidity in the SE of the band. Thus, the calculated surface dry fraction $f_{\mathrm{d}}$ is between 50 and $70 \%$ in this region, and decreases to only $20-40 \%$ in the NW part (Fig. 8a). 


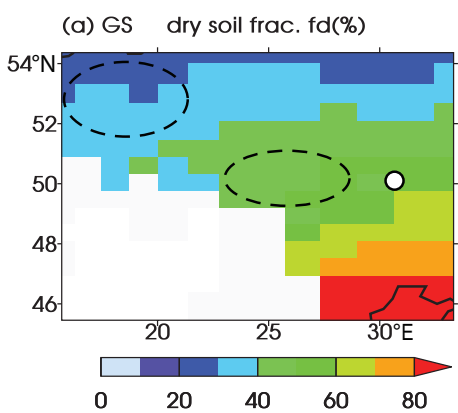

(d) GS veget. factor fv

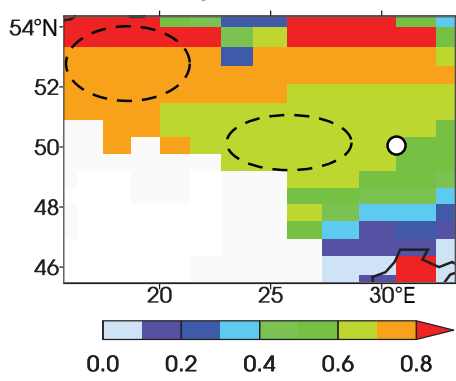

(g) GS erodible frac. E(\%)

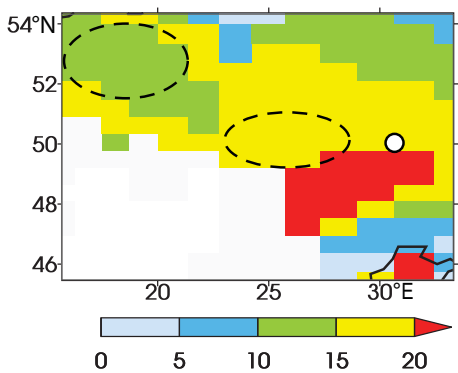

(b) HE-GS dry soil frac. fd(\%)

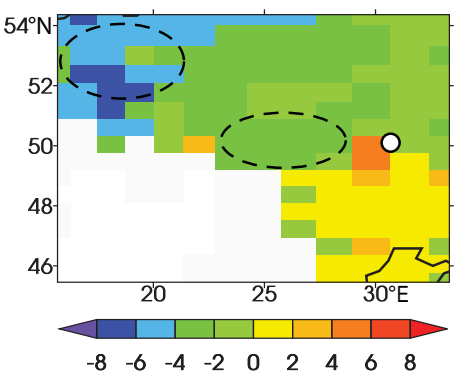

(e) HE-GS veget. factor fv

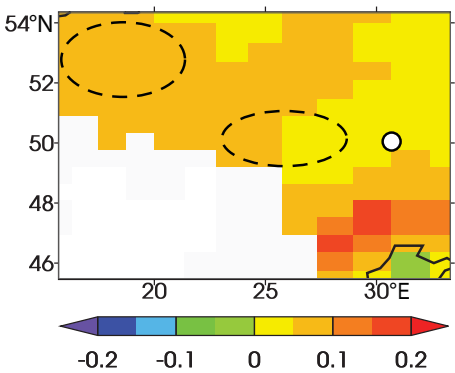

(h) HE-GS erodible frac. E(\%)

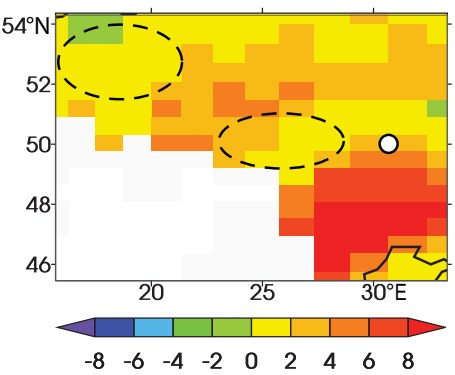

(c) GIS-GS dry soil frac. fd(\%)

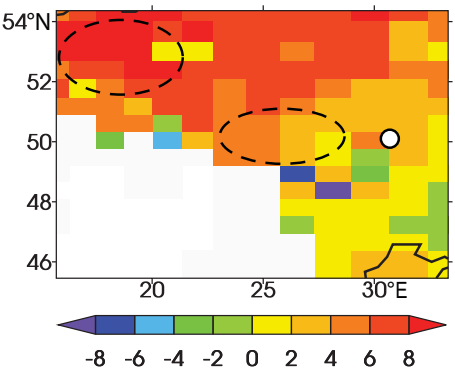

(f) GIS-GS veget. factor fv

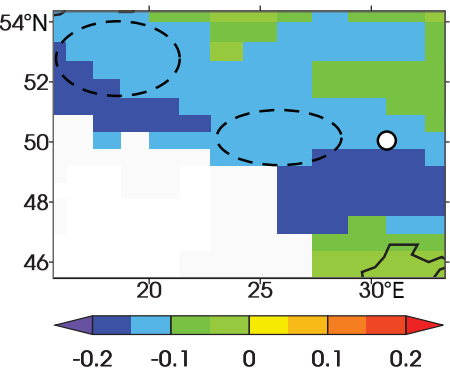

(i) GIS-GS erodible frac. E(\%)

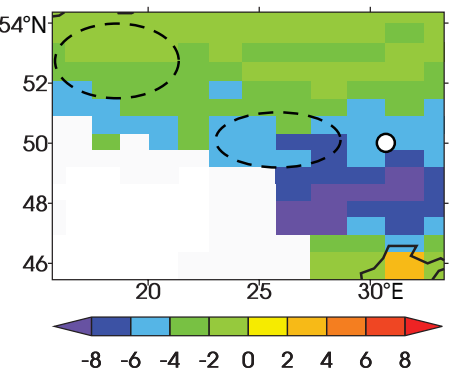

Fig. 8. Averages over the dust emission period (February to June) for dry soil fraction $F_{\mathrm{d}}$, vegetation factor $F_{\mathrm{V}}$, and erodible soil fraction $E$ in the GS state (left column), and anomalies HE-GS (center column) and GIS-GS (right column). Masked in white are the Carpathians (altitudes exceeding $500 \mathrm{~m}$ ) and the lowlands inside the mountain arch (cf. Sect. 3.1).

In our simulations, vegetation development is only determined by temperature. Hence the onset of the growth season starts later in the NW of the emission band. Thus, on average over the February to June interval, the vegetation inhibiting effect is less effective in the NW of the emission band (mean vegetation factor $\left.f_{\mathrm{v}}>0.7\right)$ than in the $\mathrm{SE}\left(f_{\mathrm{v}}<0.5\right)$ (Fig. 8d). The two spots clearly appearing in Fig. 4a as preferential emission areas have high $f_{\mathrm{v}}$ values: $0.6-0.7$ for Spot 1, and more than 0.7 for Spot 2. When calculating the erodible fraction $E$ (Fig. 8g), a combination of $f_{\mathrm{d}}$ and $f_{\mathrm{v}}$, the gradient in the dry fraction of the surface, $f_{\mathrm{d}}$, prevails. Thus, on average over the dusty season, $E$ is lower in the NW of the deflation band (10-15\% in Spot 2) than in the SE (15-20\% in Spot 1 and more than $25 \%$ south of Stayky).

Dust emission fluxes depend on the erodible fraction and the cube of $10 \mathrm{~m}$ wind speed, combined at a fine timescale ( $6 \mathrm{~h}$ in our case). The average $10 \mathrm{~m}$ wind speed increases from less than $5 \mathrm{~m} \mathrm{~s}^{-1}$ in the SE to more than $6 \mathrm{~m} \mathrm{~s}^{-1}$ in the NW (Fig. 7g). This increase prevails in the flux calculation over the decrease of $E$, resulting in stronger dust emission in the NW than in SE of the deflation band. Thus, as shown in Fig. 4, more dust is emitted in Spot 1 than in Spot 2 on average over the year (or over the dusty season; the total amount is practically the same). Both spots can be identified in Fig. $7 \mathrm{~d}$ and $\mathrm{g}$ as areas of relatively high $10 \mathrm{~m}$ wind speed and low precipitation in our investigated domain. The region of relatively high erodible fraction (25-30\%) south of Stayky does not correspond to high emission, because the wind is not strong enough.

The differences of seasonality between spots 1 and 2 (Fig. 6) can also be explained by considering the spatial distribution of temperature and precipitation averaged over the dusty season (Fig. 7a and d), and the general evolution in the investigated area of the wind speed, soil humidity (both decreasing from winter to summer) and vegetation cover (better developed in summer than in winter). In all states, it is colder in Spot 2 than in Spot 1, located more to the south, while the average precipitation amounts are quite similar. Considering 
the temperature impact on soil humidity and vegetation, this explains why the emission period is delayed in Spot 2 compared to Spot 1 (by 1 month; Fig. 6). It also explains why in the cold GS and HE states Spot 2 is most active a month later than Spot 1, in May, in spite of the gradual decrease of the average $10 \mathrm{~m}$ wind from winter to summer. The wind weakening is compensated for by a combination of drier surface and vegetation developing later than in Spot 1 (where the maximum emission is in April).

\subsubsection{Changes of climate and surface variables in the $H$-stadial cold perturbation, and consequences on dust emission}

In the HE experiment, the lower North Atlantic SSTs imposed in the latitudinal band of $30-63^{\circ} \mathrm{N}$ result in an average cooling over the dusty season of 0.5 to $2{ }^{\circ} \mathrm{C}$ in our investigated domain (Fig. 7b), the anomaly being strongest in its W-NW part. Precipitation only locally decreases, and by a small amount compared to the reference GS state; changes are statistically insignificant in Spot 2, and barely significant in Spot 1 (Fig. 7e). The combination of these two factors increase the contrast in soil humidity between the NW and the SE of the emission band, compared to GS (Fig. 8a and b). Thus, the dry fraction $f_{\mathrm{d}}$ decreases by up to $8 \%$ in the NW, but increases in the SW by up to $6 \%$ (Fig. 8b).

In our experiments, a delay in vegetation development and lower average vegetation cover than for GS are straightforward consequences of the lower HE temperatures. Thus, the vegetation factor $f_{\mathrm{v}}$ (anti-correlated with the vegetated soil fraction, as defined in Sect. 2) is everywhere slightly higher than for GS (Fig. 8e). The resulting erodible fraction anomaly is positive almost everywhere (Fig. $8 \mathrm{~h}$ ). The surface conditions are thus better for deflation than in the GS state, but the average wind slightly decreases compared to GS over most of the deflation band (Fig. 7h). The combined effect (at fine timescale, here $6 \mathrm{~h}$ ) of these opposing variations on the dust emission change between HE and GS is contrasted along the deflation band: from a strong decrease in the NW to a slight increase in the SE (Fig. 9e). The HE fluxes are $50-80 \%$ of the GS ones in Spot 2, and 70-100\% in Spot 1. Both spots are still well identified as the most active areas in the deflation band, with yearly average dust fluxes of up to $120 \mathrm{~g} \mathrm{~m}^{-2} \mathrm{yr}^{-1}$ (Fig. 4b). The relative increase of emission fluxes south and east of Stayky is due to the increase of the erodible fraction by more than $4 \%$, in a zone where $E$ was already high for GS (20-25\%). Nevertheless, the average winds are relatively weak, implying a low frequency of significant emission events, so the average fluxes remain low $\left(<60 \mathrm{~g} \mathrm{~m}^{-2} \mathrm{yr}^{-1}\right)$.

\subsection{3 "Stadial-Interstadial" changes of climate and surface variables, and the impact on dust emission}

We now analyze the effect of a North Atlantic SST increase similar to that associated with a Dansgaard-Oeschger warming event. The imposed SST perturbation results in an average temperature increase from $1.5^{\circ}$ in the SE of our investigated domain to more than $3{ }^{\circ} \mathrm{C}$ in the NW (Fig. 7c). As in the case of the cold perturbation, there is little change in precipitation over the domain (no statistically significant change in Spot 2 , and a barely significant decrease in Spot 1; Fig. 7f). The resulting $f_{\mathrm{d}}$ anomaly is positive almost everywhere in the emission band (Fig. 8c), and higher in the NW (more than $8 \%$ ) than in the SE (up to about $4 \%$ ). This anomaly distribution reduces the SE-NW contrast of $f_{\mathrm{d}}$ compared to the GS state.

The warmer climate favors vegetation development, so that the vegetation factor $f_{\mathrm{v}}$ decreases everywhere in the domain, by 0.1 to 0.2 in the emission band (Fig. 8 f).

The resulting $E$ anomaly is also negative everywhere (Fig. 8i). The average $10 \mathrm{~m}$ wind speed decreases as well, more in the NW than in the SE of the domain, which attenuates the NW-SE wind-speed gradient along the emission band compared to the GS state (Fig. 7i). All these lead to a general decrease of the emission fluxes, which are now mostly between 40 and $100 \mathrm{~g} \mathrm{~m}^{-2} \mathrm{yr}^{-1}$ in the main spots, about half of the GS values $\left(80-160 \mathrm{~g} \mathrm{~m}^{-2} \mathrm{yr}^{-1}\right)$. The decrease is stronger than in the HE experiment in the eastern half of the band, including Spot 1 (Fig. 4c).

\subsubsection{The contribution of vegetation in modulating dust emission during the North Atlantic abrupt changes}

The Sima et al. (2009) study has shown that, for the main deflation areas of Western Europe, stadial-interstadial changes in wind, precipitation, soil moisture and snow cover did not produce changes in dust emission as important as indicated by the sedimentation changes seen in the loess profiles. It was mainly the vegetation, by its effect of inhibiting the aeolian erosion, which modulated the dust emissions in response to climate variations. The inhibition was considerably more effective in the relatively warmer GIS state (due to a better developed vegetation) than in the cold GS and HE states. In order to assess the importance of this mechanism in the area investigated here, further away from the North Atlantic region in which the abrupt climate changes originate, we analyze annual mean emission flux ratios HE/GS and GIS/GS in the absence $\left(F_{\mathrm{d}}\right.$, Fig. 9a-c) and in the presence of the vegetation effect $(F$, Fig. 9d-f).

When only taking into account the effects of surface wind and precipitation (including soil humidity and snow cover), dust emission occurs almost everywhere in our domain (Fig. 9a). Annual mean dust fluxes $\left(F_{\mathrm{d}}\right)$ in GS locally exceed $220 \mathrm{~g} \mathrm{~m}^{-2} \mathrm{yr}^{-1}$ in the two most active spots. The 
(a) Fd (g m-2 yr-1) GS

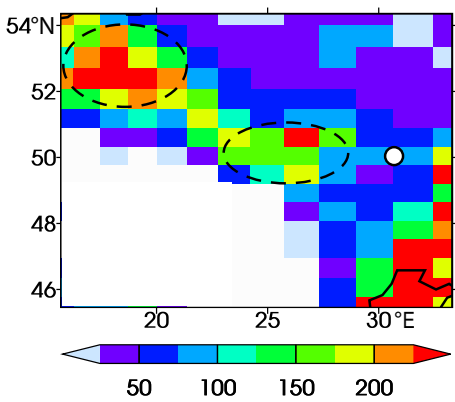

(d) $F(g ~ m-2 y r-1) G S$

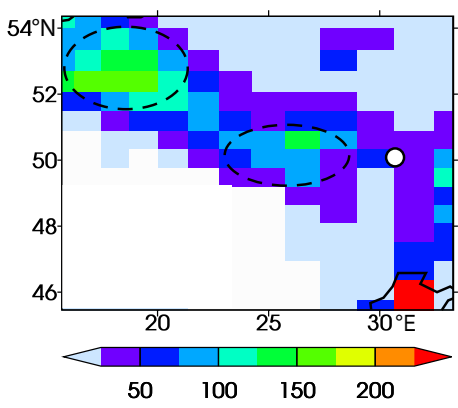

(b) Fd ratio(\%) HE/GS

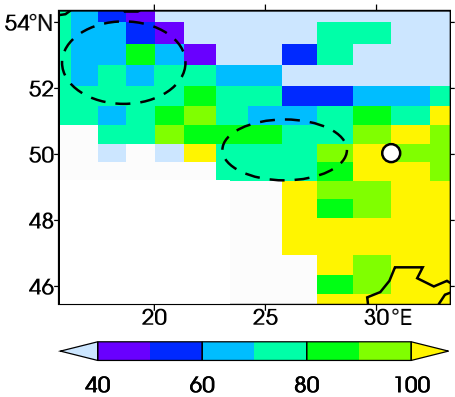

(e) $\mathrm{F}$ ratio(\%) HE/GS

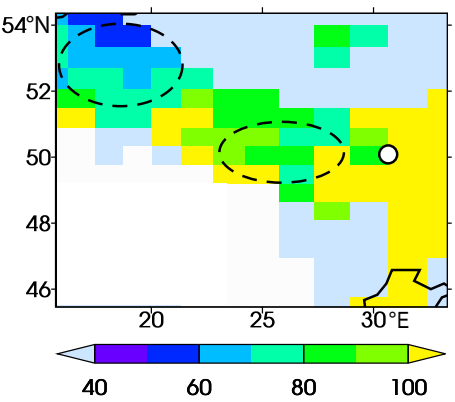

(c) Fd ratio(\%) GIS/GS

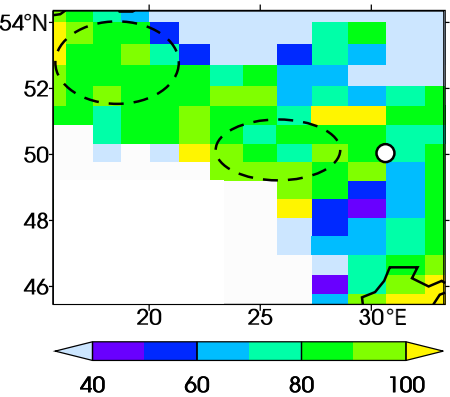

(f) F ratio(\%) GIS/GS

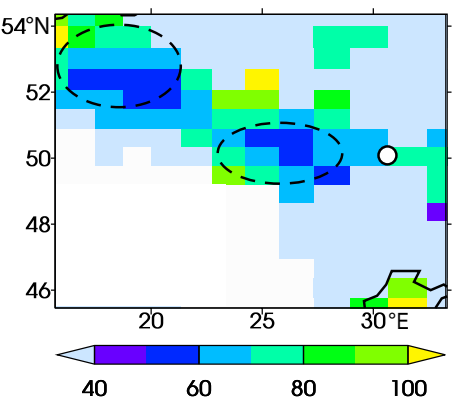

Fig. 9. Mean annual dust fluxes in the reference climate state GS (left panels) and ratios of dust fluxes HE/GS (center panels) and GIS/GS (right panels), without (a-c) and with $(\mathbf{d}-\mathbf{f})$ vegetation effect.

HE/GS and GIS/GS flux ratios are quite similar in our band of interest, mostly between 80 and $100 \%$ (Fig. 9b and c), meaning there is little difference between the perturbed and reference states. In the GIS case, these values are too high to be reconciled with the strong stadial-interstadial deposition differences indicated by the loess record. Locally, they are even higher than those for the cold HE perturbation. When adding the vegetation effect in the dust flux computation, the GS annual mean dust fluxes $(F)$ strongly decrease compared to $F_{\mathrm{d}}$ (Fig. 9d). The values in our two main spots are now generally between 80 and $160 \mathrm{~g} \mathrm{~m}^{-2} \mathrm{yr}^{-1}$. The band north and northeast of the Carpathians clearly appears as the main emission area. Here, the HE/GS flux ratio does not change much: an increase of about $10 \%$ can be seen especially in the eastern part of the domain (Fig. 9e). On the contrary, in the GIS case, a shrinking of the deflation area and a significant reduction of fluxes can be seen (Fig. 9d). The flux reduction is strongest in the most active spots, where GIS fluxes are now $50-70 \%$ of the GS ones, in better (qualitative) agreement with the loess data.

The considerable difference between annual mean emission fluxes without $\left(F_{\mathrm{d}}\right.$, Fig. 9a) and with vegetation effect $(F$, Fig. 9d) is mainly due to the shortening of the emission season, as shown by the $F_{\mathrm{d}}$ and $F$ annual cycle averaged over each of the main spots (Fig. 10). Without vegetation, emission would occur all the year round, whereas taking the vegetation effect into account restrains the emission to late winter and springtime. The same was true for the main deflation areas of Western Europe: the English Channel and the south of the North Sea (Sima et al., 2009, Fig. 5c therein). There are also some differences. In the Western European areas, in all three simulated states, the monthly mean $F_{\mathrm{d}}$ was highest in May, the month during which the attenuation of emission by the developing vegetation was also strong. Taking this effect into account resulted in a maximum emission flux $F$ in April for GIS and GS. In Spot $1, F_{\mathrm{d}}$ has similar values over the dusty season for the three states, and reaches its maximum in April, one month earlier than at the western sources. The vegetation effect in this month is considerably weaker here than in the western sources (so that the maximum of emission flux $F$ remains in April), but is strong enough to differentiate the warm perturbation from the cold states. Spot 2 is in an intermediary situation: both $F_{\mathrm{d}}$ and $F$ reach their maximum in May for GS and HE, and in April for GIS. $F_{\mathrm{d}}$ is higher for GIS than for HE, and both are smaller than for GS. It is the vegetation effect that makes the GIS fluxes become smaller than the HE ones.

\section{Discussion}

Our climate simulations and dust calculations bear some limitations and are idealized in a number of aspects. In the few years since we have run them, new efforts have been made towards better understanding various aspects of the abrupt climate changes, for example, the sub-millennial structure of DO events (e.g., Capron et al., 2010), the mechanism of stadial-interstadial oscillations (e.g., Arzel et al., 2012) or 

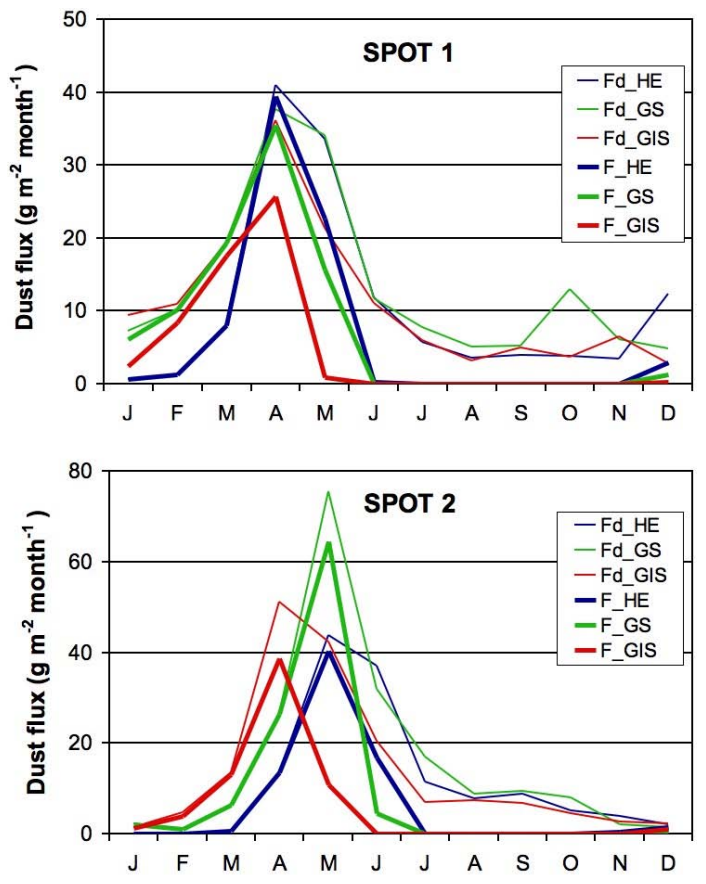

Fig. 10. Annual cycle of emitted dust flux averaged on each of the main deflation spots in the three simulated climate states, without $\left(F_{\mathrm{d}}\right)$ and with vegetation effect $(F)$.

the Heinrich event scenario (Alvarez-Solas and Ramstein, 2011). However, to date, a complete set of sea surface conditions does not exist for a sequence, GS-H-GIS, around an $\mathrm{H}$ event occurring between the beginning of the main loess sedimentation period in Europe $(\sim 40 \mathrm{kyr} \mathrm{BP})$ and the end of MIS 3 ( $\sim 25 \mathrm{kyr}$ BP) - neither reconstructed, nor from coupled model simulations.

We use LGM SSTs and sea ice extent for the reference stadial state, which otherwise is designed to correspond to $39 \mathrm{kyr}$ BP. The sea surface conditions follow a seasonal cycle, but one which does not change from one year to another. This lack of interannual variability in the boundary conditions could affect the representation of extreme wind events. As in most studies, no changes of ice sheet size and extent (and consequent adjusting of sea level) associated with the DO and $\mathrm{H}$ events are represented. The SST anomalies we apply in the North Atlantic in order to obtain the DO- and $\mathrm{H}$ event-like perturbations are highly idealized and only depend on latitude. Nevertheless, as thoroughly discussed in Sima et al. (2009), our experiment design allows us to test the impact on dust emission of changes in the North Atlantic sea surface conditions as those suggested by data for DO and $\mathrm{H}$ events. With this simple set-up, the perturbations can be ascribed to the SST anomalies over the North Atlantic only, and not to SST or sea ice differences elsewhere.

The relatively small differences of average wind and precipitation between the simulated climate states are a consequence of the imposed zonal SST anomalies of only up to
$2{ }^{\circ} \mathrm{C}$. While the maximum anomaly of $2{ }^{\circ} \mathrm{C}$ is set according to data, a more realistic distribution of SST anomalies and of the resulting sea ice might increase these differences. However, they would probably still not reach those obtained in other numerical experiments employing very contrasted boundary conditions between stadials, interstadials and $\mathrm{H}$-stadials (e.g., Hostetler et al., 1999; Renssen and Bogaart, 2003).

For forthcoming AGCM studies, an alternative to using reconstructed SSTs and prescribed perturbations would be to employ the output of a coupled global climate model (atmosphere-ocean-sea-ice-land) after regridding at the finer resolution generally required for the AGCM. This alternative, which would solve the interannual variability issue, is certainly worth exploring, especially since coupled atmosphere-ocean-sea-ice general circulation model experiments have started to address the MIS 3 period (Merkel et al., 2010; Brandefelt et al., 2011). Such simulated MIS 3 sea surface conditions would be more coherent with the rest of the numerical setup, and provide a less idealized distribution of SST anomalies. One should keep in mind however that they come with model biases, and are quite different from one model to another (cf. Brandefelt et al., 2011).

An important limitation of our simulations concerns the vegetation treatment. In the main deflation areas of Western Europe, we have imposed a glacial-type vegetation consistent with available paleodata (e.g., Woillard, 1978; de Beaulieu and Reille, 1984, 1992; Rousseau et al., 1990; Hatté et al., 1998; Peyron et al., 1998; Müller et al., 2003; Hatté and Guiot, 2005; Moine et al., 2008), only composed of boreal evergreen needleleaf trees (up to $1 \%$ of a grid cell) and C3 grass (up to $80 \%$ ). In Eastern Europe, the maximum fractional cover and the LAI limits for each PFT are prescribed to present-day values, as for the LGM PMIP experiments. As mentioned by Woillez et al. (2011), the present-day European vegetation includes considerable areas of agricultural grass; therefore the landscape is not so different from the glacial one, mainly represented by steppe or steppe-tundra. In our simulations, trees occupy less than $10 \%$ of any given grid cell of the main emission band (Fig. 9d). Grass occupies on average in the dusty season $20-35 \%$ of each grid cell in the GS state, $25-50 \%$ in the GIS state and $15-25 \%$ in the HE state, the rest of the cell being left to bare soil. Such vegetation composition seems reasonable for the time slice we approach, at about $40 \mathrm{kyr} \mathrm{BP}$, compared to the steppe or steppe-tundra predominating in Europe at the LGM.

In the NE of the domain, outside of the main band, some dust emission would occur as well if vegetation were not accounted for (Fig. 9a). Here, grid cells are occupied all year long by up to $30 \%$ trees. For the cold Greenland episodes, this might be an overestimation, but we think it has no significant impact on our results; the differences between the dust fluxes calculated without vs. with vegetation effect (Fig. 9) are the direct consequence of the fact that each grid cell is partly covered by vegetation, no matter whether trees or grass (an effect expressed by the vegetation factor $f_{\mathrm{v}}$ ). Also, 
even for the warmest simulated state, GIS, the total vegetation fraction averaged over the dusty season does not exceed $50 \%$ of a grid cell in most of the domain investigated here, which is still coherent with a steppe-tundra environment.

The adjustment of vegetation to the climate conditions is only determined by temperature in the configuration of ORCHIDEE used in this study. The glacial climates we investigate were not only colder, but also drier than today in our area of interest. More realistic simulations should also include the precipitation impact on vegetation, as well as the effect of a lower atmospheric $\mathrm{CO}_{2}$ concentration in glacial times than today. However, it is difficult to validate simulated vegetation over our area of interest for the main loess sedimentation period, due to the scarcity of pollen records compared to other parts of Europe or glacial time slices. In the frame of the Stage 3 project (Barron and Pollard, 2002), palynological data compiled from the four sites falling in our investigated domain suggest tundra and temperate grassland around $50^{\circ} \mathrm{N}, 20^{\circ} \mathrm{E}$ for the interstadials, but give no information for the stadials (Huntley et al., 2003, and references therein). For the Stayky area $\left(\sim 50^{\circ} \mathrm{N}, 30^{\circ} \mathrm{E}\right)$, Gerasimenko and Rousseau (2008) indicate a transition from a foreststeppe environment before $\sim 40 \mathrm{kyr}$ BP to steppe during the main loess sedimentation period, with arboreal pollen varying between $\sim 10 \%$ in the loess units and $\sim 40 \%$ in the paleosols. The few simulations of the MIS 3 vegetation, which could be used for comparison, either address the earlier part of MIS 3, with little loess sedimentation (e.g., GS12, at $\sim 44$ kyr BP, for Kjellström et al., 2010, or GS15-GIS14, at $\sim 55 \mathrm{kyr}$ BP, for Van Meerbeeck et al., 2011), or give results in discrepancy with the data on our area of interest (in particular for the tundra extent in central Europe; Alfano et al., 2003; Huntley et al., 2003).

In the dust emission calculations, by choosing the erosion wind threshold close to the lowest possible values (observed or derived as a function of soil characteristics), we aim to include all possibly important dust sources in our domain of study. However, using constant values for the threshold wind and the erosion potential implies homogeneous soil characteristics (obstacles and mineralogy), which is not very realistic. In the general case, the intensity and possibly even the location of the most active emission spots would be affected by taking into account the surface inhomogeneity, which implies variations of erosion threshold and potential across an investigated region. In our case, the main emission band determined by the climate-related conditions does correspond to surfaces favorable to deflation. Moreover, the erosion potential in this band decreases from NW towards SW, so, if taken into account, it would accentuate the emission flux gradient in Fig. 4a. Thus, Spot 2 falls in a roughly flat zone of Tertiary sediment, with high erosion potential. Spot 1 lies in a more complex area with Cretaceous sedimentary rocks in the western part, while in the eastern part, Neogene and less erodible Precambrian rocks are mixed (Asch, 2005).
We note that the thickest European deposits are generally located along major river valleys (of the Seine, the Rhine, the Danube, or the Dnieper). In glacial times, these valleys used to be almost dried-out most of the year. Rich in sands and silts transported by the rivers during the snow-melting period, they constituted important deflation areas. Where the relief context favored the retention of the coarse deflated material, thick deposits have formed within a short distance downwind (e.g., Antoine et al., 2001; Smalley et al., 2009). This explains the exceptional thickness (for Europe) of the loess deposits at Nussloch ( $\sim 13.5 \mathrm{~m}$ for the $40-15 \mathrm{kyr}$ BP interval in the P4 sequence; Antoine et al., 2009), on the eastern bank of the Rhine valley, in the context of prevailing westerly winds. In general, even though periglacial braided rivers used to be important local sources for the coarse material in some of the European loess deposits, such details cannot be captured at the resolution of an AGCM.

For the Stayky area, the prevailing winds are from westnorthwest (Fig. 3; see also Rousseau et al., 2007). Due to the relief configuration east of the Dnieper (a plain well exposed to wind erosion), no loess deposit has formed downwind in the close vicinity of the valley. The nearest loess deposits are located on the west bank of the river, and contain little of the easily deflatable coarse material from the valley, brought by rare strong easterly winds. In our reference sequence, the stratigraphic units corresponding to the $40-15 \mathrm{kyr}$ BP interval only add up to $\sim 6.5 \mathrm{~m}$ thickness. Thus, while both Nussloch and Stayky sites have recorded millennial climate variations, their sensitivity to the climate signal depended on the local relief context. At Stayky, without a strong local source upwind, the relative contribution of more remote sources as those we identify here must have been higher.

The emission flux calculations use 6-hourly winds, but even this high time series frequency does not capture the shorter episodes of strong wind, which mainly control the total amount of emitted dust. A way to compensate for that would be to lower the emission threshold. Changing this threshold from the $7 \mathrm{~m} \mathrm{~s}^{-1}$ value used here to $6 \mathrm{~m} \mathrm{~s}^{-1}$ obviously increases the mean annual flux (not shown), but only slightly widens the main emission areas, and does not affect the location of the most active spots or the relative differences between the simulated climate states.

The simulated monthly mean $10 \mathrm{~m}$ winds in our investigated domain during the dusty season (Fig. 6) are in agreement with the W-NW wind direction inferred from field observations by Rozycki (1967) and Léger (1990). These studies describe ridge-like features called gredas, elongated in the main wind direction, varying from NW-SE to N-S around the Carpathians.

Considering the predominant wind direction, and the distance to our reference site, Spot 1 is particularly well placed as a source for the Stayky deposits. Dust calculations only taking into account the wind and soil humidity conditions give emission fluxes by 10 to $30 \%$ lower in the warm GIS 
perturbation than in the GS reference state. Adding the vegetation effect increases the difference by another 10 to $20 \%$.

Spot 2 is the largest and most intense deflation area of the simulated emission band in the reference GS experiment, without as well as with the vegetation effect. In the GIS simulation, dust fluxes are only by up to $20 \%$ smaller than in the reference state before applying the vegetation inhibition factor. The vegetation effect further reduces them by $20-30 \%$.

The vegetation effect not only determines a strong decrease of the GIS emission fluxes compared to the GS ones, particularly in the most active spots, but also decreases the size of the band where significant emission occurs (Figs. 4 and 9). Without a transport and deposition model, the impact on the sedimentation rates cannot be calculated. Nevertheless, as the simulated slightly lower precipitation and slightly stronger winds in the GS and HE states favor transport compared to the GIS state, we may reasonably suppose that considerably more emitted dust would lead to considerably more deposition during the cold North Atlantic episodes than during the relatively warmer ones, in agreement with the loess data. For example, at Nussloch (Germany), stadial loess sedimentation rates are up to 5 times higher than the interstadial ones (Rousseau et al., 2007). Thus, the key role of vegetation in modulating stadial-interstadial dust emission variations is confirmed.

Also, in both main spots, the GIS surface winds are lower than the GS ones, not only on average over the dusty season (Fig. 7i), but also on average over each month of that season (not shown). This result is consistent with the grain size variations in the Stayky loess profile, indicating a coarser sedimentation in stadial than in interstadial episodes.

Concerning the $\mathrm{H}$-stadials, our modeling experiments suggest a reduction of dust emission with respect to a stadial state. When only taking into account the wind and soil humidity effects, the simulated emission flux decrease is even stronger locally than for the interstadial. Including the effect of vegetation, less developed in a colder climate, attenuates the difference of emission fluxes between a stadial and an $\mathrm{H}$-stadial (whereas it amplifies the stadial-interstadial differences, as seen above). In our experiments, the flux ratio $\mathrm{HE} / \mathrm{GS}$ is up to $10 \%$ higher with than without the vegetation effect, but the HE fluxes remain smaller than the GS ones. This is somehow counterintuitive, because colder climates are associated with higher loess sedimentation rates, generally interpreted as a result of stronger winds and dryer conditions, favoring both the emission and the transport of dust. This is certainly true for "cold and dry" vs. "warm and humid" climates, like glacial (loess sedimentation) vs. interglacial (no loess sedimentation) or, at a finer timescale, stadial (high loess sedimentation rate) vs. interstadial (reduced or no sedimentation).

The emission attenuation suggested by our experiments for an H-stadial compared to a stadial state can be understood if we think of the difference between stadial and $\mathrm{H}$ stadial as a change from "cold and dry" to "colder and drier".
Indeed, the lower dust emission fluxes in our HE experiment than in the GS one are associated with lower precipitation and weaker winds, the former favoring dust transport, the later hindering it. Again, a transport and deposition model would be needed to determine the net effect on the sedimentation rates in the investigated domain, and more specifically at the reference site. But even if we used such a model, loess stratigraphy offers no element to confront the results, as there is practically no way to distinguish between dust layers deposited at different rates in similarly dry conditions.

In the case of interstadials, the lower emission activity is associated with wetter soil conditions, favorable to pedogenesis, and the resulting soils (well developed or in embryonic form only) are distinguishable in the sediment (Rousseau et al., 2007, 2011). In contrast, only exceptionally is it possible to find in stratigraphic profiles particular features susceptible to be associated with $\mathrm{H}$ events. It is the case of the millimetric sandy laminations identified in particular loess units at the Nussloch loess site, in Germany, resulting from a combination of strong wind events and coarser deposition (Lautridou et al., 1985; Derbyshire and Mellors, 1988). Otherwise, loess studies suggest that $\mathrm{H}$ events only could be associated to peaks in some very detailed grain size index records (Porter and An, 1995; Antoine et al., 2001, 2009; Rousseau et al., 2002, 2007). In theory, if such records had a fine enough resolution, and the different variations could be dated with a reasonable precision, it would be possible to distinguish the sedimentation rates corresponding to the different climate episodes. In practice, to date, no loess profile allows such quantitative estimations. Qualitatively, as the sandy laminations, the grain size peaks (reflecting coarser deposition) are interpreted as indicating episodes of particularly strong wind. Such very strong winds are able to bring more medium to coarse material from the nearby sources to the considered deposition site, while from the remote sources still only finer material can travel the longer distance. Thus, the coarser deposition also reflects an increased relative contribution of the nearby vs. remote emission areas to the sedimentation at a given site.

Looking at the numerical results from this perspective, we note that for Spot 1, close to Stayky, the monthly mean emission fluxes are the highest in the month of April of the HE state (Fig. 6). Also, the average wind in April for HE in Spot 1 is directed eastward at the $850 \mathrm{hPa}$ level as well as at $10 \mathrm{~m}$ (not shown). So, it is in the HE state, during this particular month, that Spot 1 may have the highest contribution to dust deposition at Stayky of all months and analyzed climate states. In addition, in the grid cell corresponding to Stayky, the few strongest $10 \mathrm{~m}$ wind events over the year, exceeding $20 \mathrm{~m} \mathrm{~s}^{-1}$ on average over $6 \mathrm{~h}$, also occur in April (and in December, but this is outside the dusty season). Even though in this cell the emission dust flux for HE in the month of April is lower than in the main emission spots, $20-25 \mathrm{~g} \mathrm{~m}^{-2}$ month $^{-1}$ only, the proximity to the deposition site makes it an important potential contributor to the Stayky sediments. Thus, 
our modeling results support the identification of $\mathrm{H}$ events in loess sequences as peaks in the grain size index.

\section{Conclusions}

Following the Sima et al. (2009) study on the impact of North Atlantic abrupt climate changes on dust emission in Western Europe, and the correlation proposed by Rousseau et al. (2011) between Greenland, West and East European dust records, we have focused here on the Eastern European dust sources. The same simulations have been used, including a reference Greenland stadial experiment GS, and two perturbations, seen as sensitivity tests with respect to changes in the North Atlantic surface conditions: a Greenland interstadial (GIS) and a H-stadial (HE) (i.e., the cold climate episode associated with a Heinrich event). We have combined results from these numerical experiments and dust emission calculations with information from the loess site of Stayky, in Ukraine.

A band stretching north and northeast of the Carpathians appears as an important deflation area, a potential source for the Eastern European loess deposits located around $50^{\circ} \mathrm{N}$ latitude. Two spots are particularly active, one in Ukraine (Spot 1) and the other in Poland (Spot 2). Located westnorthwest from Stayky, they are well placed to be the main dust sources for our reference site.

The general conclusions of the previous study on Western Europe (strong seasonality of emissions, difference of dusty season from one climate state to another, higher emission fluxes in the stadial than in the interstadial state, importance of the vegetation) are found to apply to Eastern Europe as well.

In the deflation band identified here, taken as a whole, emissions mainly occur from February to June in the GS experiment (compared to February-May in the west), from March to June in the HE experiment (same in the west), and from February to May in the GIS simulation (February-April in the west). Thus, the beginning of the dusty season, constrained by soil humidity and snow conditions, is the same for east and west, while the end, determined by vegetation development, is slightly later in the east in the GIS and GS states. The resemblances are due to the fact that in our simulations there are no strong differences of precipitation or temperature (the main variables impacting the continental surface conditions) between west and east along the $\sim 50^{\circ} \mathrm{N}$ latitudinal band where the main deflation areas are located. The differences are mainly due to a delay in vegetation development in Spot 2, still allowing some emissions later than in the other investigated sources.

Indeed, a more detailed analysis for the area investigated here shows differences (a) between spots 1 and 2 for each climate state, and (b) from one climate state to another for each spot individually. In our simulations, they are caused by the differences of temperature (indirectly, via the impact on soil humidity and vegetation), due to the geographical position in the case of (a), because Spot 2 is more to the north, closer to the ice sheet, and due to the imposed North Atlantic SST anomalies in the case of (b).

Furthermore, in the main deflation band in Eastern Europe, emission fluxes in the GIS experiment are $50-70 \%$ of the GS ones (the ratio was less than $10 \%$ for the English Channel area, and 10 to $80 \%$ for the area south of the North Sea, including the exposed continental shelf). The vegetation, better developed in the warmer climate, and thus protecting the soil more efficiently from aeolian erosion, is responsible for about half of the flux difference. Its contribution in modulating the response of dust emission intensity to the North Atlantic millennial variability is less important than in the main Western European sources, but still significant. The simulated weaker winds and slightly higher precipitation in interstadial conditions suggest less favorable conditions for transport than in a stadial. The modeling results are thus qualitatively consistent with the stadial-interstadial sedimentation variations in the Stayky loess profile, and in the European loess sequences in general.

In the HE experiment, emission fluxes are generally lower than the GS ones. The simulated climate is slightly drier, but also slightly less windy over the region studied here. A transport and deposition model would be needed to evaluate the resulting change of average sedimentation rate at a loess site; the resolution and dating uncertainties of the available loess profiles do not allow a comparison with such a result anyway. A more detailed analysis than in the previous study allows us nevertheless to investigate the hypothesis suggested by some loess data studies, i.e., that $\mathrm{H}$-stadials could be identified in some of the most detailed loess profiles as peaks of the grain size index. Such peaks represent brief intervals of coarser sedimentation due to particularly strong winds, increasing the relative contribution of the nearby vs. remote sources. Our simulations support this interpretation, pointing to the month of April of the HE experiment as the month with the strongest winds in the immediate vicinity of Stayky, where some dust mobilization occurs, and the highest dust emission in the main deflation Spot 1, only a few hundred kilometers away, associated with dominant $850 \mathrm{hPa}$ winds directed towards the Stayky area, likely to transport more relatively coarser material to our reference site.

This study proposes another way to put together loess data and climate simulations to critically assess the modeling results, and test data interpretation. Investigating mechanisms and regional details strongly benefits from the "zoom" capacity of the LMDZ AGCM, and from analyzing the results at timescales ranging from yearly averages down to high frequency time series ( $6 \mathrm{~h}$ in our case).

For our future simulations we will consider two main changes: forcing the AGCM with sea surface conditions issued by MIS 3 simulations with a coupled ocean-atmosphere model, instead of the GLAMAP2000 dataset for the LGM, and imposing a vegetation distribution consistent with the 
simulated glacial climates instead of the present-day distribution. Also, the effect of precipitation will be taken into account along with that of temperature in computing the vegetation changes. We also plan to simulate the entire dust cycle (emission, transport and deposition), in view of a more quantitative comparison to European loess data.

Acknowledgements. This study was supported by the French Agence Nationale pour la Recherche (ANR) through the ACTES project ANR-08-BLAN-0227/CSD-6. The simulations were performed using High Performace Computing resources of the Commissariat à l'Energie Atomique, France. The manuscript has benefited from the comments of three anonymous reviewers. This is LSCE contribution no. 5000 and LDEO contribution no. 7694.

Edited by: V. Rath

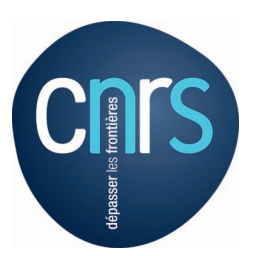

The publication of this article is financed by CNRS-INSU.

\section{References}

Alfano, M. J., Barron, E. J., Pollard, D., Huntley, B., and Allen, J. R. M.: Comparison of climate model results with European vegetation and permafrost during oxygen isotope stage three, Quaternary Res., 59, 97-107, doi:10.1016/s0033-5894(02)00012-1, 2003.

Alvarez-Solas, J. and Ramstein, G.: On the triggering mechanism of Heinrich events, P. Natl. Acad. Sci. USA, 108, E1359-E1360, doi:10.1073/pnas.1116575108, 2011.

Antoine, P., Rousseau, D. D., Zöller, L., Lang, A., Munaut, A. V., Hatté, C., and Fontugne, M.: High-resolution record of the last interglacial-glacial cycle in the loess palaeosol sequences of Nussloch (Rhine Valley - Germany), Quatern. Int., 76/77, 211-229, 2001.

Antoine, P., Catt, J., Lautridou, J. P., and Somme, J.: The loess and coversands of northern France and southern England, J. Quaternary Sci., 18, 309-318, 2003a.

Antoine, P., Coutard, J. P., Gibbard, P., Hallegouët, B., Lautridou, J. P., and Ozouf, J. C.: The Pleistocene rivers of the English Channel region, J. Quaternary Sci., 18, 227-243, 2003 b.

Antoine, P., Rousseau, D. D., Moine, O., Kunesch, S., Hatté, C., Lang, A., Tissoux, H., and Zöller, L.: Rapid and cyclic aeolian deposition during the Last Glacial in European loess: a highresolution record from Nussloch, Germany, Quaternary Sci. Rev., 28, 2955-2973, doi:10.1016/j.quascirev.2009.08.001, 2009.

Antoine, P., Rousseau, D. D., Degeai, J.-P., Moine, O., Lagroix, F., Kreutzer, S., Fuchs, M., Hatté, C., Gauthier, C., Svoboda, J., and Lisa, L.: High-resolution record of the environmental response to climatic variations during the Last Interglacial-Glacial cycle in Central Europe: the loess-paleosol sequence of Dolni Vestonice (Cezch Republic), Quaternary Sci. Rev., 67, 17-38, doi:10.1016/j.quascirev.2013.01.014, 2013.
Arzel, O., England, M. H., de Verdiere, A. C., and Huck, T.: Abrupt millennial variability and interdecadal-interstadial oscillations in a global coupled model: sensitivity to the background climate state, Clim. Dynam., 39, 259-275, doi:10.1007/s00382011-1117-y, 2012.

Asch, K.: The 1:5 Million Geological Map of Europe and Adjacent Areas, BRG - Bundesanstalt für Geowissenschaften und Rohstoffe, Hannover, Germany, 2005.

Auffret, J. P.: Les formations sédimentaires holocènes du domaine prélittoral picard, Bulletin de l'Association française pour l'Etude du Quaternaire, 1-2, 34, 1980.

Auffret, J. P., Horn, R., Larsonneur, C., Curry, D., and Smith, A. J.: La Manche orientale, carte des paléovallées et des bancs sableux, Bureau des recherches Géologiques et Minières, Orléans, 1982.

Balkanski, Y., Schulz, M., Claquin, T., Moulin, C., and Ginoux, P.: The formulation of dust emissions on global scale: Formulation and validation using satellite retrievals, in: Emissions of Atmospheric Trace Compounds, edited by: Granier, C., Artaxo, P., and Reeves, C., Kluwer Academic Publishers, Dordrecht, the Netherlands, 239-267, 2004.

Bard, E., Menot-Combes, G., and Rostek, F.: Present status of radiocarbon calibration and comparison records based on Polynesian corals and Iberian Margin sediments, Radiocarbon, 46, 11891202, 2004.

Barron, E. and Pollard, D.: High-resolution climate simulations of oxygen istopose stage 3 in Europe, Quaternary Res., 58, 296309, 2002.

Berger, A. and Loutre, M. F.: Insolation values for the climate of the last 10 millions years, Quaternary Sci. Rev., 10, 297-317, 1991.

Berger, A. L.: Long-term variations of caloric insolation resulting from the Earth's orbital elements, Quaternary Res., 9, 139-167, 1978.

Braconnot, P.: Modeling the last glacial maximum and mid-holocene, C. R. Geosci., 336, 711-719, doi:10.1016/j.crte.2003.12.023, 2004.

Brandefelt, J., Kjellström, E., Näslund, J.-O., Strandberg, G., Voelker, A. H. L., and Wohlfarth, B.: A coupled climate model simulation of Marine Isotope Stage 3 stadial climate, Clim. Past, 7, 649-670, doi:10.5194/cp-7-649-2011, 2011.

Broecker, W., Bond, G., Klas, M., Clark, E., and McManus, J.: Origin of the northern Atlantic's Heinrich events, Clim. Dynam., 6, 265-273, 1992.

Capron, E., Landais, A., Chappellaz, J., Schilt, A., Buiron, D., Dahl-Jensen, D., Johnsen, S. J., Jouzel, J., Lemieux-Dudon, B., Loulergue, L., Leuenberger, M., Masson-Delmotte, V., Meyer, H., Oerter, H., and Stenni, B.: Millennial and sub-millennial scale climatic variations recorded in polar ice cores over the last glacial period, Clim. Past, 6, 345-365, doi:10.5194/cp-6-3452010, 2010.

Cortijo, E., Labeyrie, L., Vidal, L., Vautravers, M., Chapman, M., Duplessy, J. C., Elliot, M., Arnold, M., Turon, J. L., and Auffret, G.: Changes in sea surface hydrology associated with Heinrich event 4 in the North Atlantic Ocean between 40 degrees and 60 degrees N, Earth Planet. Sc. Lett., 146, 29-45, doi:10.1016/s0012-821x(96)00217-8, 1997.

Dansgaard, W., Johnsen, S. J., Clausen, H. B., Dahi-Jensen, D., Gundestrup, N. S., Hammer, C. U., Hvidberg, C. S., Steffensen, J. P., Sveinbjöprnsdottir, A. E., Jouzel, J., and Bond, G.: Evidence for general instability of past climate from a 250 -kyr ice-core 
record, Nature, 364, 218-220, 1993.

de Beaulieu, J. L. and Reille, M.: The pollen sequence of Les Échets (France) : a new element for the chronology of the Upper Pleistocene, Geogr. Phys. Quatern., XXXVIII, 3-9, 1984.

de Beaulieu, J. L. and Reille, M.: The last climatic cycle at La Grande Pile (Vosges, France) a new pollen profile, Quaternary Sci. Rev., 11, 431-438, 1992

Derbyshire, E. and Mellors, T. W.: Geological and geotechnical characteristics of some loess and loessic soils from China and Britain - A comparison, Eng. Geol., 25, 135-175, doi:10.1016/0013-7952(88)90024-5, 1988.

Ducoudre, N. I., Laval, K., and Perrier, A.: Sechiba, a New Set of Parameterizations of the Hydrologic Exchanges at the Land Atmosphere Interface within the Lmd Atmospheric GeneralCirculation Model, J. Climate, 6, 248-273, 1993.

Ehlers, J., Gibbard, P., and Hughes, P. D.: Quaternary Glaciations - Extent and Chronology, Development in Quaternary Studies, edited by: van der Meer, J., Elsevier, Amsterdam, 1126 pp., 2011.

Fryrear, D. W.: Soil Cover and Wind Erosion, Trans. ASAE, 28, 781-784, 1985.

Fuchs, M., Kreutzer, S., Rousseau, D. D., Antoine, P., Hatté, C., Lagroix, F., Moine, O., Gauthier, C., Svoboda, J., and Lisá, L.: The loess sequence of Dolní Vestonice, Czech Republic: A new OSL-based chronology of the Last Climatic Cycle, Boreas, 42, 664-677, doi:10.1111/j.1502-3885.2012.00299.x, 2013

Gerasimenko, N. and Rousseau, D. D.: Stratigraphy and paleoenvironments of the last Pleniglacial in the Kyiv loess region (Ukraine), Quaternaire, 19, 293-307, 2008.

Haase, D., Fink, J., Haase, G., Ruske, R., Pecsi, M., Richter, H., Altermann, M., and Jager, K. D.: Loess in Europe - its spatial distribution based on a European Loess Map, scale $1: 2,500,000$, Quaternary Sci. Rev., 26, 1301-1312, 2007.

Haesaerts, P., Borziak, I., Chirica, V., Damblon, F., Koulakovska, L., and van der Plicht, J.: The east Carpathian loess record: a reference for the middle and late pleniglacial stratigraphy in central Europe, Quaternaire, 14, 163-188, 2003.

Hatté, C. and Guiot, J.: Palaeoprecipitation reconstruction by inverse modelling using the isotopic signal of loess organic matter: application to the Nussloch loess sequence (Rhine Valley, Germany), Clim. Dynam., 25, 315-327, doi:10.1007/s00382-0050034-3, 2005.

Hatté, C., Fontugne, M., Rousseau, D. D., Antoine, P., Zöller, L., Tisnérat-Laborde, N., and Bentaleb, I.: $\delta^{13} \mathrm{C}$ variations of loess organic matter as a record of the vegetation response to climatic changes during the Weichselian, Geology, 26, 583-586, 1998.

Heinrich, H.: Origin and Consequences of Cyclic Ice Rafting in the Northeast Atlantic Ocean during the Past 130,000 years, Quaternary Res., 29, 142-152, 1988.

Hostetler, S. W., Clark, P. U., Bartlein, P. J., Mix, A. C., and Pisias, N. J.: Atmospheric transmission of North Atlantic Heinrich events, J. Geophys. Res., 104, 3947-3952, 1999.

Huntley, B., Alfano, M. J., Allen, J. R. M., Pollard, D., Tzedakis, P. C., de Beaulieu, J. L., Grüger, E., and Watts, B.: European vegetation during Marine Oxygen Isotope Stage-3, Quaternary Res., 59, 195-212, 2003.

Jost, A., Lunt, D., Kageyama, M., Abe-Ouchi, A., Peyron, O., Valdes, P. J., and Ramstein, G.: High-resolution simulations of the last glacial maximum climate over Europe: a solution to discrepancies with continental palaeoclimatic reconstructions?,
Clim. Dynam., 24, 577-590, doi:10.1007/s00382-005-0009-4, 2005.

Juvigné, E.: Contribution à la connaissance de la stratigraphie au Quaternaire par l'étude des minéraux denses transparents entre l'Eifel et le Massif Central français et plus particulièrement en Belgique, Département de Géographie, Liège, Liège, 235 pp., 1976.

Kjellström, E., Brandefelt, J., Naslund, J. O., Smith, B., Strandberg, G., Voelker, A. H. L., and Wohlfarth, B.: Simulated climate conditions in Europe during the Marine Isotope Stage 3 stadial, Boreas, 39, 436-456, doi:10.1111/j.1502-3885.2010.00143.x, 2010.

Krinner, G., Viovy, N., de Noblet-Ducoudre, N., Ogee, J., Polcher, J., Friedlingstein, P., Ciais, P., Sitch, S., and Prentice, I. C.: A dynamic global vegetation model for studies of the coupled atmosphere-biosphere system, Global Biogeochem. Cy., 19, Gb1015, doi:10.1029/2003gb002199, 2005.

Kukla, G.: Pleistocene land-sea correlations, 1. Europe, Earth-Sci. Rev., 13, 307-374, 1977.

Laurent, B., Marticorena, B., Bergametti, G., Chazette, P., Maignan, F., and Schmechtig, C.: Simulation of the mineral dust emission frequencies from desert areas of China and Mongolia using an aerodynamic roughness length map derived from the POLDER/ADEOS 1 surface products, J. Geophys. Res.-Atmos., 110, D18s0, doi:10.1029/2004jd005013, 2005.

Lautridou, J. P., Sommé, J., Heim, J., Puisségur, J. J., and Rousseau, D. D.: La stratigraphie des loess et formations fluviatiles d'Achenheim (Alsace): Nouvelles données bioclimatiques et corrélations avec les séquences Pléistocènes de la France du Nord-Ouest, in: Dynamical and chronological relations between glacial and periglacial deposits, edited by: Campy, M., Bulletin de l'Association française pour l'étude du Quaternaire, 22-23, 125-132, 1985.

Léger, M.: Loess Landforms, Quatern. Int., 7/8, 53-61, 1990.

Marticorena, B. and Bergametti, G.: Two-year simulations of seasonal and interannual changes of the Saharan dust emissions, Geophys. Res. Lett., 23, 1921-1924, 1996.

Martinson, D. G., Pisias, N. G., Hays, J. D., Imbrie, J., Moore, T. C., and Shackleton, N. J.: Age dating and the orbital theory of the Ice ages : development of a high-resolution 0 to 300,000-year chronostratigraphy, Quaternary Res., 27, 1-29, 1987.

Merkel, U., Prange, M., and Schulz, M.: ENSO variability and teleconnections during glacial climates, Quaternary Sci. Rev., 29, 86-100, doi:10.1016/j.quascirev.2009.11.006, 2010.

Moine, O., Rousseau, D. D., and Antoine, P.: The impact of Dansgaard-Oeschger cycles on the loessic environment and malacofauna of Nussloch (Germany) during the Upper Weichselian, Quaternary Res., 70, 91-104, doi:10.1016/j.yqres.2008.02.010, 2008.

Müller, U. C., Pross, J., and Bibus, E.: Vegetation response to rapid climate change in Central Europe during the past 140,000 yr based on evidence from the Füramoos pollen record, Quaternary Res., 59, 235-245, 2003.

North Greenland Ice Core Project: High-resolution record of Northern Hemisphere climate extending into the last interglacial period, Nature, 431, 147-151, 2004.

Peltier, W. R.: Ice-Age Paleotopography, Science, 265, 195-201, 1994. 
Petit, J. R., Jouzel, J., Raynaud, D., Barkov, N. I., Barnola, J. M., Basile, I., Bender, M., Chappellaz, J., Davis, M., Delaygue, G., Delmotte, M., Kotlyakov, V. M., Legrand, M., Lipenkov, V. Y., Lorius, C., Pépin, L., Ritz, C., Saltzman, E., and Stievenard, M.: Climate and atmospheric history of the past 420,000 years from the Vostok ice core, Antarctica, Nature, 399, 429-436, 1999.

Peyron, O., Guiot, J., Cheddadi, R., Tarasov, P., Reille, M., De Beaulieu, J. L., Bottema, S., and Andrieu, V.: Climatic reconstruction in Europe for 18,000 YR B.P. from Pollen Data, Quaternary Res., 49, 183-196, 1998.

Porter, S. C. and An, Z. S.: Correlation between climate events in the North Atlantic and China during the last glaciation, Nature, 375, 305-308, 1995.

Renssen, H. and Bogaart, P. W.: Atmospheric variability over the $\sim 14.7 \mathrm{kyr}$ BP stadial-interstadial transition in the North Atlantic region as simulated by an AGCM, Clim. Dynam., 20, 301-313, 2003.

Rousseau, D. D., Puisségur, J. J., and Lautridou, J. P.: Biogeography of the Pleistocene Pleniglacial malacofaunas in Europe, Stratigraphic and climatic implications, Palaeogeogr. Palaeocl., 80, 7-23, 1990.

Rousseau, D. D., Gerasimenko, N., Matviischina, Z., and Kukla, G.: Late Pleistocene environments of the Central Ukraine, Quaternary Res., 56, 349-356, 2001.

Rousseau, D. D., Antoine, P., Hatté, C., Lang, A., Zöller, L., Fontugne, M., Ben Othman, D., Luck, J. M., Moine, O., Labonne, M., Bentaleb, I., and Jolly, D.: Abrupt millennial climatic changes from Nussloch (Germany) Upper Weichselian eolian records during the Last Glaciation, Quaternary Sci. Rev., 21, 1577-1582, 2002.

Rousseau, D. D., Kukla, G., and McManus, J.: What is what in the ice and the ocean?, Quaternary Sci. Rev., 25, 2025-2030, 2006.

Rousseau, D. D., Sima, A., Antoine, P., Hatté, C., Lang, A., and Zöller, L.: Link between European and North Atlantic abrupt climate changes over the last glaciation, Geophys. Res. Lett., 34, L22713, doi:10.1029/2007g1031716, 2007.

Rousseau, D. D., Antoine, P., Gerasimenko, N., Sima, A., Fuchs, M., Hatté, C., Moine, O., and Zoeller, L.: North Atlantic abrupt climatic events of the last glacial period recorded in Ukrainian loess deposits, Clim. Past, 7, 221-234, doi:10.5194/cp-7-2212011, 2011.
Rozycki, S. Z.: Le sens des vents portant la poussière de loess à la lumière de l'analyse des formes d'accumulation du loess en Bulgarie et en Europe Centrale, Revue de Géomorphologie dynamique, 1, 1967.

Sarnthein, M., Gersonde, R., Niebler, S., Pflaumann, U., Spielhagen, R., Thiede, J., Wefer, G., and Weinelt, M.: Overview of Glacial Atlantic Ocean Mapping (GLAMAP 2000), Paleoceanography, 18, 8-1-8-6, 2003.

Siddall, M., Rohling, E. J., Thompson, W. G., and Waelbroeck, C.: Marine isotope stage 3 sea level fluctuations: Data synthesis and new outlook, Rev. Geophys., 46, RG4003, doi:10.1029/2007rg000226, 2008.

Sima, A., Rousseau, D. D., Kageyama, M., Ramstein, G., Schulz, M., Balkanski, Y., Antoine, P., Dulac, F., and Hatté, C.: Imprint of North-Atlantic abrupt climate changes on western European loess deposits as viewed in a dust emission model, Quaternary Sci. Rev., 28, 2851-2866, doi:10.1016/j.quascirev.2009.07.016, 2009.

Smalley, I., O'Hara-Dhand, K., Wint, J., Machalett, B., Jary, Z., and Jefferson, I.: Rivers and loess: The significance of long river transportation in the complex event-sequence approach to loess deposit formation, Quatern. Int., 198, 7-18, doi:10.1016/j.quaint.2008.06.009, 2009.

Van Meerbeeck, C. J., Renssen, H., Roche, D. M., Wohlfarth, B., Bohncke, S. J. P., Bos, J. A. A., Engels, S., Helmens, K. F., Sanchez-Goni, M. F., Svensson, A., and Vandenberghe, J.: The nature of MIS 3 stadial-interstadial transitions in Europe: New insights from model-data comparisons, Quaternary Sci. Rev., 30, 3618-3637, doi:10.1016/j.quascirev.2011.08.002, 2011.

Wang, X., Ma, Y., Chen, H., Wen, G., Chen, S., Tao, Z., and Chung, Y. S.: The relation between sandstorms and strong winds in Xinjiang, China, Water Air Soil Poll., 3, 67-79, 2003.

Woillard, G.: Grande Pile Peat Bog: A Continuous Pollen Record for the Last 140,000 Years, Quaternary Res., 9, 1-21, 1978.

Woillez, M.-N., Kageyama, M., Krinner, G., de Noblet-Ducoudré, N., Viovy, N., and Mancip, M.: Impact of $\mathrm{CO}_{2}$ and climate on the Last Glacial Maximum vegetation: results from the ORCHIDEE/IPSL models, Clim. Past, 7, 557-577, doi:10.5194/cp7-557-2011, 2011. 